\section{Climatological analysis of forest fires occurred in 2011 over Turkey and their associations with hydroclimatic, surface weather and upper atmosphere conditions}

\author{
Türkiye'de 2011'de oluşan \\ orman yangınlarının \\ klimatolojik çözümlemesi ve \\ hidroklimatik, yüzey hava ve \\ yüksek atmosfer koşulları ile \\ bağlantılari ${ }^{1}$
}

\author{
Murat Türkeş ${ }^{2}$ \\ Gökhan Altan ${ }^{3}$
}

\begin{abstract}
Purpose of the study is to analyse spatial and temporal distribution patterns and causes of forest fires in Turkey in the year 2011, based on the Keetch-Byram Drought Index (KBDI) calculated by using data of 75 climatology/ meteorology stations and to determine the relationship between hydroclimatic, synopticscale surface weather and upper atmosphere conditions, and occurrence time and magnitude of the fires. Wildfires became one of the most important disasters for Turkish forests in 2011, which are considered within the Mediterranean macro-climate belt and biome. KBDI calculated for 2011 reached the highest values in August and September, and spatially in the west and southern regions of the Anatolian Peninsula characterised with the Mediterranean climate. In the summer 2011 that was hotter and drier than the normal at the Eastern Mediterranean, northern Mesopotamia, west and south regions of Turkey, August had the largest burned area, whereas September was characterised with maximum number of forest fires. According to fire determination ratios, $40 \%$ of fire frequency and $36 \%$ of burned areas are closely linked to fire-prone hydro-climatic
\end{abstract}

\section{Özet}

Çalışmanın amacı, Türkiye'de 2011 ylında çıkan orman yangınlarının alansal ve zamansal dağglış desenlerini ve nedenlerini, 75 klimatoloji/ meteoroloji istasyonunun verileriyle hesaplanan Keetch-Byram Kuraklık İndisi'ne (KBDI) göre çözümlemek ve yangınların oluş zamanı ve büyüklüğü ile hidroklimatik, sinoptik ölçekli yüzey hava ve yüksek atmosfer koşulları arasındaki ilişkileri belirlemektir. Orman Yangınları, Akdeniz büyük iklim kuşağında ve biyomunda yer alan Türkiye ormanları için, 2011 yilinda da en önemli afetlerden biri olmuştur. 2011 y1l için hesaplanan KBDI, en yüksek değerlerine Ağustos ve Eylül aylarında ve alansal olarak Anadolu Yarımadası'nın Akdeniz iklimi ile nitelenen batı ve güney bölgelerinde ulaștı. Doğu Akdeniz, Kuzey Mezopotamya ve Türkiye'nin batı ve güney bölgelerinde normalden daha sicak ve daha kurak geçen 2011 yazında, Ağustos en geniş yanan alana sahipken, Eylül en fazla sayıda orman yangınıyla nitelendi. Yangin belirleme oranlarina göre, yangin s1kllğının \% 40'1 ve yanan alanların \% 36's1 oldukça yüksek bir yangın olayı olasillğıyla nitelenen yangina uygun hidroklimatolojik ve sinoptik ölçekli hava koşullarıyla yakından

\footnotetext{
${ }^{1}$ Bu çalışmanın bazı ilk bulguları, AÜ Türkiye Coğrafyası Araştırma ve Uygulama Merkezi (TÜCAUM) tarafindan 18-19 Ekim 2012 tarihlerinde düzenlenen VII. Coğrafya Sempozyumu'nda bildiri olarak sunuldu.

${ }^{2}$ Prof. Dr., İstatistik Bölümü Bağlantll Orta Doğu Teknik Üniversitesi, comu.muratturkes@gmail.com

${ }^{3}$ Uzman Coğrafya Öğretmeni, Karşıyaka Kız Teknik ve Meslek Lisesi, Sivas, comu.gokhanaltan@gmail.com
} 
Türkeş, M., \& Altan, G. (2014). Türkiye'de 2011'de oluşan orman yangınlarının klimatolojik çözümlemesi ve hidroklimatik, yüzey hava ve yüksek atmosfer koşulları ile bağlantilar1. International Journal of Human Sciences, 11(1), 145-176.

and synoptic-scale weather conditions with a bağlantılıdır.

considerable high probability of fire event.

Anahtar kelimeler: Türkiye, hidroklimatoloji, Keywords: Turkey, hydroclimatology, drought, kuraklık, Keetch-Byram Kuraklik İndisi, Hava Keetch-Byram Drought Index, Weather type tipi analizi analysis

\section{(Extended English abstract is found at the end} of the paper)

\section{Giriş}

Doğal süreçlerle değişme eğiliminde olan iklim, yüzey ve atmosferik değissiklikler ile bunların değişkenliklerini de kapsayan çeşitli insan etkileri ve etkinlikleri sonucunda, günümüzde önceki dönemlere göre daha değişken bir özellik kazanmıştır. Özellikle sanayi devrimi ile artan fosil yakıt kullanımı, madencilik etkinlikleri, sanayi süreçleri, arazi kullanım değişiklikleri ve ormansızlaşma gibi insan etkinlikleri, iklimdeki doğal değişkenlik üzerinde olumsuz etkiler yaratmıştır (Carvalho ve ark., 2011; Öztürk ve ark., 2012; Türkeş, 2008ab, 2011, 2012a). Bu insan etkinlikleri arasında ormansızlaşma önemli bir yere sahiptir. Arazi kullanımı, arazi kullanımı değişikliği ve orman yangınları ile kaybedilen orman alanları son yıllarda büyük bir artış göstermiştir (Altan ve ark., 2011; Flannigan ve ark., 2000; Tatlı ve Türkeş, 2013; Türkeş, 2007, 2012b; Türkeş ve Altan, 2013ab; Türkeş ve ark., 2011a, 2012). Ormansızlaşma süreci ile bu olumsuz değişikliklerden en fazla etkilenenler arasında orman ekosistemi ve biyoçeşitliliği gelir.

Türkiye'de, geçen 10 yıllar boyunca özellikle kış yăğşlarında azalma, ilkbahar ve yaz ortalama, ortalama maksimum (en yüksek) ve özelikle ortalama minimum (en düşük) hava sıcaklıklarında kayda değer bir artış eğilimi gözlenmiştir (Türkeş, 2011, 2012a, 2013; Türkeş ve ark., 2002; Türkeş ve Sümer, 2004). Buna bağlı olarak, sırasıyla İç Anadolu, Ege ve Akdeniz bölgelerinde egemen olan yarıkurak/kuru-yarınemli, yarınemli ve yarınemli/nemli koşullarda daha kurağa doğru önemli değissiklikler belirlenmiştir (Türkeş, 1999, 2011, 2012b, 2013; Türkeş ve ark.., 2009; vb.). Kuraklığın etkisi ile Ege, Trakya, İç ve Güneydoğu Anadolu'da yüzey ve yer altı su kaynaklarına olan ihtiyaç artmış ve bu kaynaklarda önemli azalmalar kaydedilmiştir (Türkeş ve Altan, 2011, 2013ab; Altan ve ark., 2011; Türkeş, 1996, 1998, 1999, 2003, 2012ab; Türkeş ve ark., 2005, 2009; Yıldırım ve ark., 2004). Gözlenen kurak koşullar ve hava sıcaklıklarındaki artış eğilimleri, orman yangınları açısından olumsuz koşulların yaşanabileceği ortamlara zemin hazırlar. Türkiye'de özellikle 2008 yılında yaşanan kurak koşulların etkisi sonucu çok sayıda ve geniş alanlı orman yangınları ile karşılaşılması bu duruma örnektir (Türkeş ve Altan, 2011, 2012bc). Gelecekte Akdeniz Havzası, Türkiye ve bölgesinde beklenen daha sıcak ve daha kurak, değişkenliğin daha yüksek, ekstrem hava ve iklim olaylarına ve afet etkilerine daha açık hava ve iklim koşullarında (örn. Altınsoy ve ark., 2011, 2012; Carvalho ve ark., 2011; Flannigan ve ark., 2000; Sen ve ark., 2012; 
Türkeș, M., \& Altan, G. (2014). Türkiye'de 2011'de olușan orman yangınlarının klimatolojik çözümlemesi ve hidroklimatik, yüzey hava ve yüksek atmosfer koşulları ile bağlantilar1. International Journal of Human Sciences, 11(1), 145-176.

Ozturk ve ark., 2011, 2012, 2013; Türkeş, 2011, 2012b; Türkeş ve ark., 2011a; vb.), orman yangınlarının sıklığı, şiddeti ve yanan alanların büyüklügünde önemli artışlar oluşması beklenmektedir.

Orman yangınlarını oluşturan etmenler arasında kurak koşullarla birlikte sıcak hava dalgaları da yer almaktadır. Sıcak hava dalgalarının en önemli olumsuz sonuçlarından biri de orman yangınlarıdır. Sıcaklığın ani artışlar gösterdiği dönemlerde etkili olan sıcak hava dalgaları sonucunda orman yangınlarında ve kurak koşullarda bir artış eğilimi egemen olur (Carvalho ve ark., 2008; Erlat ve Türkeş, 2013; Kuglitsch ve ark., 2010; Tatlı ve Türkeş, 2013; Türkeş, 2007, 2010, 2012ab; vb.).

Bitkilerdeki su varlığı ve toprak nemi kuraklık etkisine bağlı olarak azalabilir. Toprağın üst katmanındaki ormanaltı bitkiler ve daha derinlerde bulunan organik maddelerin yanıcıllğı, evapotranspirasyon ve yağışıı etkisi ile kümülatif bir şekilde nemi azaltmaya devam eder. Bu nem azlığ1 ve bitkilerin yanıcıllğ̣ üzerinde kuraklığın şiddetli etkisi görülür (Altan, 2011; Altan ve ark., 2011; Keetch ve Byram, 1968; Janis ve ark., 2002; Goodrick, 2003; Dolling ve ark, 2005; Tatli ve Türkeş, 2013; Türkeş ve ark., 2011a; Türkeş ve Altan, 2012abc, 2013ab). Yapılan bazı çalışmalardaysa, KBDI ile bitki nemi arasındaki farklıllğın bitki türleri arasında bile görülebileceği kanıtlandı (Xanthopoulos ve ark., 2006). Orman yangınlarına neden olabilecek koşullar böylece kuraklıkla birlikte bitkilerin yanıcı madde özelliği kazanmasına bağlı olarak da gerçekleşir (Altan ve ark., 2011; Carvalho ve ark., 2008; Türkeş ve Altan, 2012abc; Türkeş ve ark., 2011a). Türkiye'de de her yıl bu şekilde oluşan çok sayıda orman yangınında, geniş orman alanları zarar görür ve büyük ekonomik kayıplar oluşur.

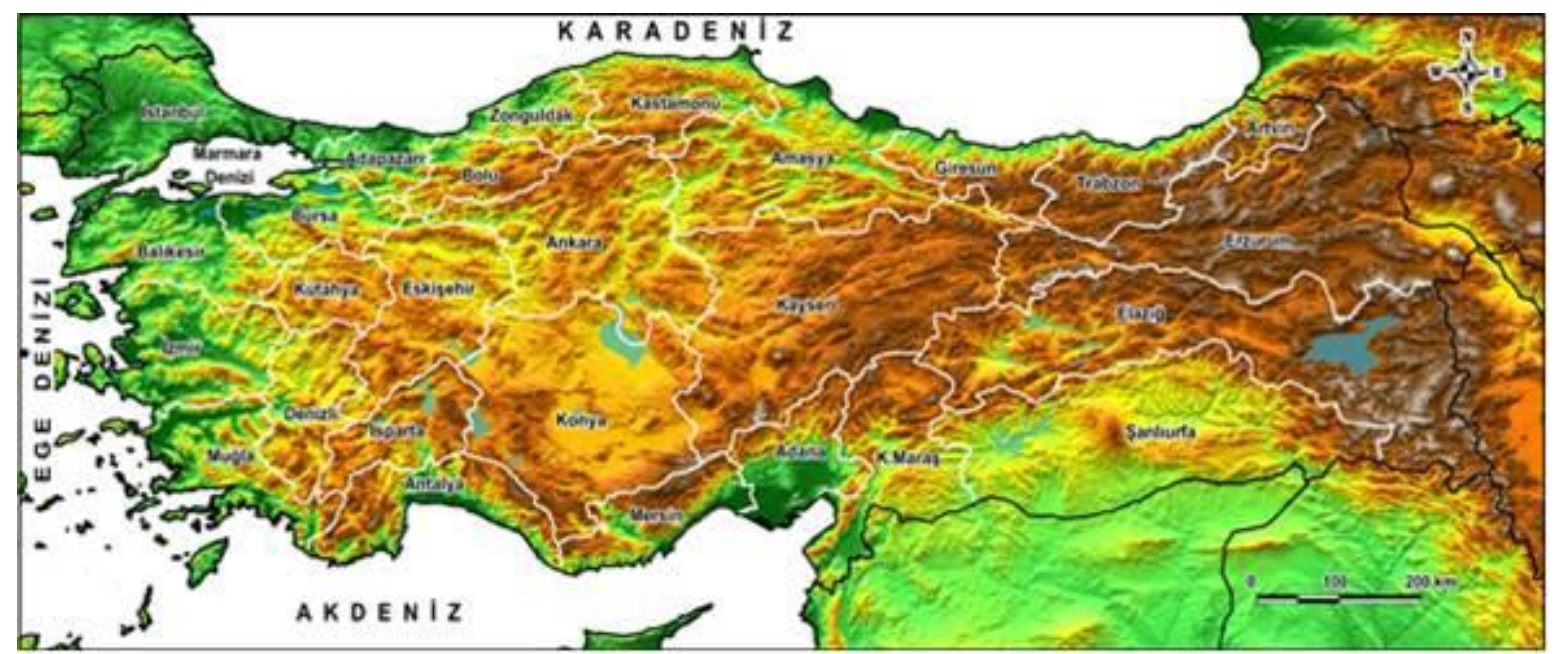

Şekil 1. Türkiye’de 2011 yılının Ekim ayında yapılan değişikliklere göre oluşturulan yeni OBM’ler.

Çalışmanın amacı, 2011 yılında Türkiye'de kurulu orman bölge müdürlükleri (OBM’ler) sorumluluğundaki orman alanlarında (Şekil 1) çıkan yangınların hidroklimatolojik ve meteorolojik 
Türkeș, M., \& Altan, G. (2014). Türkiye'de 2011'de olușan orman yangınlarının klimatolojik çözümlemesi ve hidroklimatik, yüzey hava ve yüksek atmosfer koşulları ile bağlantilar1. International Journal of Human Sciences, 11(1), 145-176.

koşullarla ilişkisini değerlendirmek, orman yangınlarında görevli yangın yöneticilerine orman yangınları açısından riskli günleri belirleyen KBDI yöntemini kullanarak bilgi sağlamak ve gelecekte oluşabilecek orman yangınlarının oluşumu ve gelişimi ile ilgili bilimsel bulgu ve değerlendirmeleri paylaşmaktır.

Türkiye, subtropikal Akdeniz iklim kuşağ1 içerisinde yer alan, özellikle batı ve güney bölgeleri olmak üzere büyük bir bölümü yazları sıcak ve/ya da çok sıcak ve kurak, kışları 1lık ve yağışı bir ülkedir. Bu özelliğine bağlı olarak, yaz aylarında yüksek hava sıcaklıklarından ve şiddetli yaz kuraklıklarının etkisiyle yaz döneminde geniş alanları etkileyen büyük orman yangınları geniş orman alanlarının zarar görmesine neden olur (Altan, 2011; Altan ve ark., 2011; Moriondo ve ark., 2006; Türkeş, 2007, 2012ab; Türkeş ve Altan, 2012abc, 2013ab; Türkeş ve ark., 2011a, 2012). Bu yüzden, bu makalede, Türkiye’deki büyük orman yangınlarıyla bağlantılı egemen hidroklimatolojik ve meteorolojik denetçilerin, özellikle sinoptik ve yarımküresel ölçekli hava sistemlerinin rolünü daha iyi açıklayabilmek amacıyla, hidroklimatolojik, sinoptik klimatolojik ve meteorolojik değerlendirmelerde en geniş anlamıyla Akdeniz Havzası ölçeğinde çalışıldı.

\section{Veri ve Yöntem}

\subsection{Veri}

Çalışma için Türkiye'nin çeşitli coğrafi bölgelerinden seçilen TC Orman ve Su İşleri Bakanlığı, Meteoroloji Genel Müdürlüğ̈’ne bağlı 75 meteoroloji istasyonu belirlenirken, istasyonların gözlem süreleri göz önünde bulunduruldu. Seçilen istasyonların Türkiye'nin en uzun süreli gözlem yapan istasyonları olmasına özen gösterildi (Şekil 2).

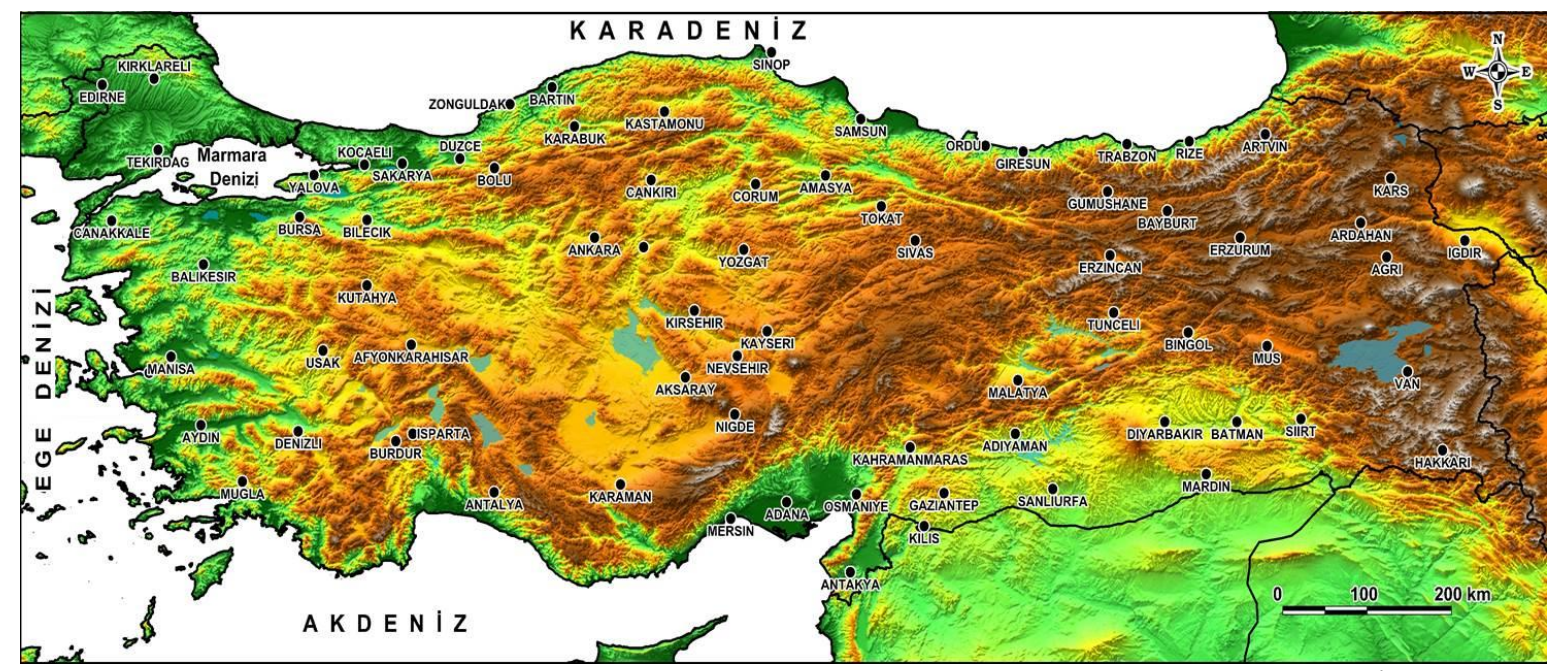

Şekil 2. Çalışma için Türkiye'nin çeşitli bölgelerinden seçilen klimatoloji/meteoroloji istasyonlarının coğrafi dağılışı.

İkinci önemli veri kaynağı, Amerika Birleşik Devletleri (ABD) Ticaret Bakanlığ1 Ulusal Okyanus ve Atmosfer Kurumu (NOAA), Yer Sistemi Araştırma Laboratuvarı (ESRL) Fiziksel 
Türkeș, M., \& Altan, G. (2014). Türkiye'de 2011'de olușan orman yangınlarının klimatolojik çözümlemesi ve hidroklimatik, yüzey hava ve yüksek atmosfer koşulları ile bağlantilar1. International Journal of Human Sciences, 11(1), 145-176.

Bilimler Bölümü (PSD) (kısaca, NOAA/ESRL/PSD) NCEP Uygulamalı Veri Seti ve NCEP/NCAR Reanalysis (Yeniden çözümleme) veri tabanlarındaki hava ve iklim veri tabanı ve harita analiz olanaklarıdır (Kalnay ve ark., 1996; Anonim, 2013a).

$\mathrm{Bu}$ kapsamda, geniş Akdeniz Havzası için, çoğunlukla günlük ve aylık NOAA/ESRL/PSD-NCEP/NCAR yeniden çözümleme veri tabanına dayanarak, 2011 yaz mevsimi (Haziran, Temmuz, Ağustos) ve Ağustos ayının, (a) birleşik ortalama toplam yağış tutarı (mm) ve (b) 1951-2010 dönemi klimatolojisine göre birleşik yağış anomalisi (mm); (c) birleşik ortalama yüzey yağış oranı (mm/gün) ve (d) anomalisi (mm/gün); (e) birleşik ortalama 0-10 cm kısmi toprak nemi ya da su içeriği (kısmi su içeriği * 100 = \%) ve (f) anomalisi; (g) birleşik ortalama yüzey hava sıcaklığı $\left({ }^{\circ} \mathrm{C}\right)$ ve (h) anomalisi $\left({ }^{\circ} \mathrm{C}\right)$; (1) $1000 \mathrm{hPa}-300 \mathrm{hPa}$ kalınlığında birleşik ortalama atmosferik dikine bağıl nem (\%) ve (i) anomalisi (\%); çoğunlukla günlük NOAA/ESRL/PSD_ NCEP Uygulamalı Veri Seti'ne dayanarak, 17-18 Ağustos ve 1-2 Eylül 2011 günlerinin, (a) ortalama deniz düzeyi basıncı (hPa) ve (b) 1951-2010 dönemi klimatolojisine göre anomalisi (hPa); (c) ortalama yüzey (burada verilmedi) ve vektörel yüzey rüzgarı $(\mathrm{m} / \mathrm{s})$ ve (d) anomalileri $(\mathrm{m} / \mathrm{s})$; (e) birleşik ortalama yüzey rüzgarı şiri $(\mathrm{m} / \mathrm{s})$ ve (f) anomalisi $(\mathrm{m} / \mathrm{s})$; (g) ortalama $850 \mathrm{hPa}$ jeopotansiyel yükseklik (dam) ve (h) anomalisi (dam) verileri elde edildi (Şekil 10, 11, 12, 13, 14, $15)$.

Burada geçen 'birleşik' (kompozit) kavramı, NCEP/NCAR Yeniden Çözümleme veri tabanı ve konuyla ilgili başka veri setlerine ait değişkenlerin 1981-2010 dönemi uzun süreli ortalama (1981-2010 klimatolojisi), ortalama ya da anomalilerinin günlük birleşik (ortalama ya da yağış ve buharlaşma için ortalama toplam) değerleridir. Başka bir deyişle, örneğin birleşik ortalama ve birleşik anomali, aynı değişkenin NCEP/NCAR Yeniden Çözümleme veri tabanı dahil çeşitli kaynaklardan sağlanan verilerin ortalamalarından elde edilen ortalama ve anomalilere karşıllk gelmektedir.

Üçüncü grup önemli veri kaynağı, TC Orman ve Su İşleri Bakanlı̆̆ı’na bağlı Orman Genel Müdürlüğü’nün 2011 y1lı orman yangınları sıralacıdır (OGM, 2012). Bu kaynaktan sağlanan ham yangın verilerinden yararlanarak, 2011 yılinda oluşan orman yangınları ile yanan alanların OBM’lere göre dağılışı haritalandırıldı. Ayrıca yangın sayısı ve yanan alanların aylara ve mevsimlere göre dağılışları çeşitli grafiklerle ortaya konularak, Keetch-Byram kuraklık indisi sonuçları ile ilişkileri değerlendirildi.

\subsection{Yöntem}

Çalışmada orman yangınları için riskli günleri belirlemek, yangınları tahmin etmek ve önlemek, oluşan yangınlara erken müdahale etmek amacıyla, ABD ve pek çok ülkenin orman 
Türkeș, M., \& Altan, G. (2014). Türkiye'de 2011'de olușan orman yangınlarının klimatolojik çözümlemesi ve hidroklimatik, yüzey hava ve yüksek atmosfer koşulları ile bağlantilar1. International Journal of Human Sciences, 11(1), 145-176.

koruma ile ilgili birimlerinde oldukça geniş bir kullanım alanına sahip olan Keetch-Byram Kuraklık İndisi (KBDI) kullanıld1 (Keetch ve Byram, 1968; Alexander, 1990; Janis ve ark., 2002; Heim, 2002; Goodrick, 2003; Dolling ve ark, 2005; Yamak, 2006; Altan, 2011; Altan ve ark., 2011; Türkeş ve ark., 2011b; Türkeş ve Altan, 2012abc). KBDI, havanın yağışlı ya da yağısssız olmasına bağlı olarak aşağıdaki kurallar ve eşitlikler temel alınarak hesaplanır:

Eğer KBDI hesaplaması yapılacak istasyonun ilgili gününde yağış $(P)$ yoksa ve maksimum sicaklık $\left(T_{\text {mak }}\right) 6.78^{\circ} \mathrm{C}$ 'den küçükse $\left(P=0, T_{\text {mak }}<6.78^{\circ} \mathrm{C}\right)$, Denk. (1) kullanılır:

$$
I(t)=I(t-1)
$$

Eğer yağış yok ve maksimum sıcaklık $6.78{ }^{\circ} \mathrm{C}$ 'den büyükse $\left(P=0, T_{\text {mak }}>6.78{ }^{\circ} \mathrm{C}\right)$, Denk. (2) kullanilir:

$$
I(t)=I(t-1)+k f(t)
$$

Eğer yağ1ş var ve 24 saatlik yağış toplam1 $5.1 \mathrm{~mm}$ 'den az ise $\left(P \neq 0, P_{24}<5.1 \mathrm{~mm}\right)$, Denk. (2)'ye dönülür. Buna karşl1ık, eğer yağış var ve 24 saatlik yağış $5.1 \mathrm{~mm}$ 'den fazla ise $\left(P \neq 0, P_{24}>5.1\right.$ mm), hesaplama aşağıda verilen Denk. (3) kullanılarak yapılır:

$$
I(t)=\left[I(t-1)-39.37 \cdot P_{24}\right]+k f(t)
$$

Yukarıda verilen denklemlerden elde edilen sonuç aşağıda verilen kuraklık etmeni formülünde yerine yazıllırsa kuraklık indisi hesaplanmış olur. Başka sözlerle, seçilen herhangi bir istasyonun ilgili herhangi bir gününde KBDI değerinin hesaplaması aşağıda verilen Denk. (4) ile yapilir:

$$
k f(t)=\frac{[800-I(t-1)] \cdot\left[\left(0.968 \cdot \exp \left(0.0875 \cdot T_{m a k}\right)+1.5552\right)-8.3\right]}{1000 \cdot\left[1+10.88 \cdot \exp \left(-0.0174 \cdot \overline{P_{y i l}}\right]\right.}
$$

Denklemlerde; $P$, kuraklık etmeni hesaplanacak günün yağış tutarını $(\mathrm{mm}) ; T_{\text {mak, }}$ günlük maksimum hava sıcaklığını $\left({ }^{\circ} \mathrm{C}\right) ; P_{24}$, son 24 saatteki toplam yağıșı $(\mathrm{mm}) ; \bar{P}_{y l l}$, yıllık ortalama yağış tutarını $(\mathrm{mm}) ; \mathrm{kf}(t), t$ zamanındaki kuraklık etmenini; I, KBDI değerini gösterir (Keetch ve Byram, 1968; Janis ve ark., 2002; Goodrick, 2003; Dolling, 2005; Altan ve ark., 2011).

Yukarıda verilen denklemler sonucunda hesaplanan Keetch-Byram Kuraklık İndis değeri, Çizelge 1'de verilen bir değere karşılık gelir ve ilgili günün kuraklık indisine göre orman yangını çıkma olasıllığ belirlenmiş olur (Keetch ve Byram, 1968). Bu indis değerinin OBM’lerde, günün en yüksek (maksimum) sıcaklık değerlerine ulaşılan, yerel saat ile 14:00 ve 15:00 saatleri arasında otomatik hava gözlem istasyonlarından gerçek zamanlı (anlık) güncellenen veriler kullanılarak hesaplanmasıyla, yangın olasılı̆̆ının hangi bölümlerde arttı̆̆ı elektronik olarak izlenebilir. Bu yolla 
Türkeș, M., \& Altan, G. (2014). Türkiye'de 2011'de olușan orman yangınlarının klimatolojik çözümlemesi ve hidroklimatik, yüzey hava ve yüksek atmosfer koşullanı ile bağlantiları. International Journal of Human Sciences, 11(1), 145-176.

da, indis değerleri hangi bölümlerde yangının çıkacağını olasılıkla önceden öngörebilir (Altan, 2011; Türkeş ve Altan, 2012abc). Bu durumun örnekleri, ABD’de Texas ve Florida gibi pek çok eyaletin orman servislerinde bulunabilir (Janis ve ark., 2002; Anonim, 2013bc).

Çizelge 1. Keetch-Byram kuraklık indis değerine göre yangın tehlike olasıllkları (Keetch ve Byram 1968; Janis ve ark., 2002'ye göre yeniden düzenlendi).

\begin{tabular}{|c|c|c|}
\hline Sinif & İndis değeri & Yangın ç1kma olasılı̆̆1 \\
\hline 0 & $0-99$ & Yangin olasiliğ yok \\
\hline 1 & $100-199$ & Yangın olasıliğ düşük \\
\hline 2 & $200-299$ & Yangin olasiliğ orta düzeyde \\
\hline 3 & $300-399$ & Yangin olasıliğ yüksek düzeyde \\
\hline $\begin{array}{l}4 \\
5\end{array}$ & $\begin{array}{l}400-499 \\
500-599\end{array}$ & Yangin olasilĭg oldukesa yü̈ksek düzeyde \\
\hline $\begin{array}{l}6 \\
7\end{array}$ & $\begin{array}{l}600-699 \\
700-800\end{array}$ & Kesin yangin olur \\
\hline
\end{tabular}

Bu çalışmada ise orman yangınlarının gelecekte tahmin edilmesine yönelik uygulamaların yerine, kuraklık indisi ile 2011 yllında Türkiye genelinde oluşan orman yangınlarının karşılaştırılması gerçekleştirildi. 2011 yılında oluşan orman yangınlarının meydana geldiği günlerin kuraklık indisine göre yangın sınıfı belirlenerek indisin 2011 yılında yangınları yakalama yüzdesi tespit edildi. Buna göre, indisin yangınları en riskli sınıflarda yakalama oranına göre başarı oranı ortaya konuldu (Şekil 8 ve 9).

(a) Yangin sayısı

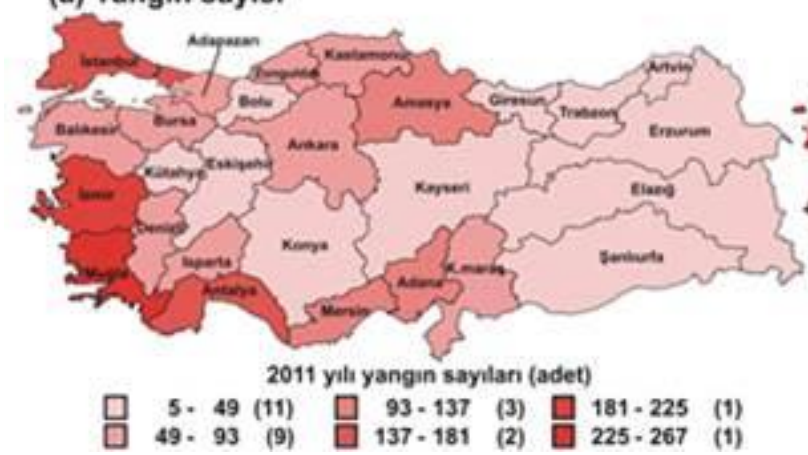

(b) Yanan alan

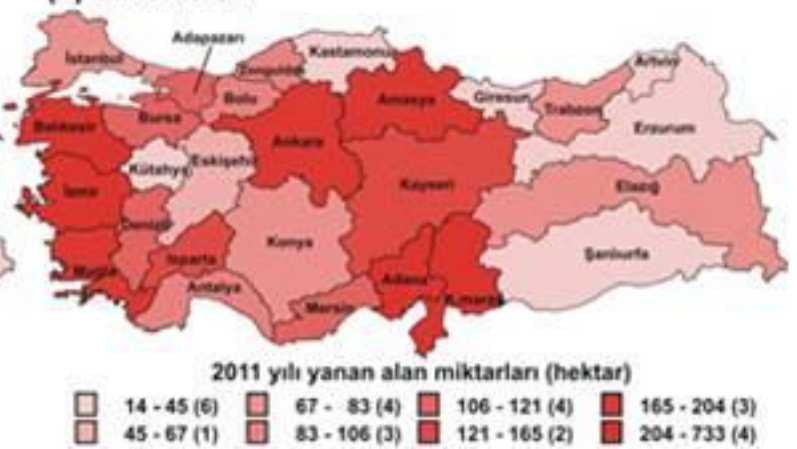

Şekil 3. Türkiye'de 2011 yılında oluşan (a) orman yangınları ve (b) yanan alanların OBM’lere göre dağılışı (lejantta parantez içerisindeki sayılar OBM sayısını gösterir).

\section{Araştırma Bulguları}

\subsection{1 y1lı Orman Yang1nlar1}

Türkiye'de, 2011 yılında oluşan 1954 orman yangınında 3612 hektar (ha) orman alanı zarar gördü (OGM, 2012). 2011 yıllnda Türkiye'de en fazla orman yangını 27 orman bölge müdürlüğü arasında 267 orman yangınıyla Muğla'da oluşurken, en fazla yanan alan 733 ha ile İzmir'de gözlendi (Şekil 3 ve Şekil 4a). 
Türkeș, M., \& Altan, G. (2014). Türkiye'de 2011'de olușan orman yangınlarının klimatolojik çözümlemesi ve hidroklimatik, yüzey hava ve yüksek atmosfer koşulları ile bağlantilar1. International Journal of Human Sciences, 11(1), 145-176.
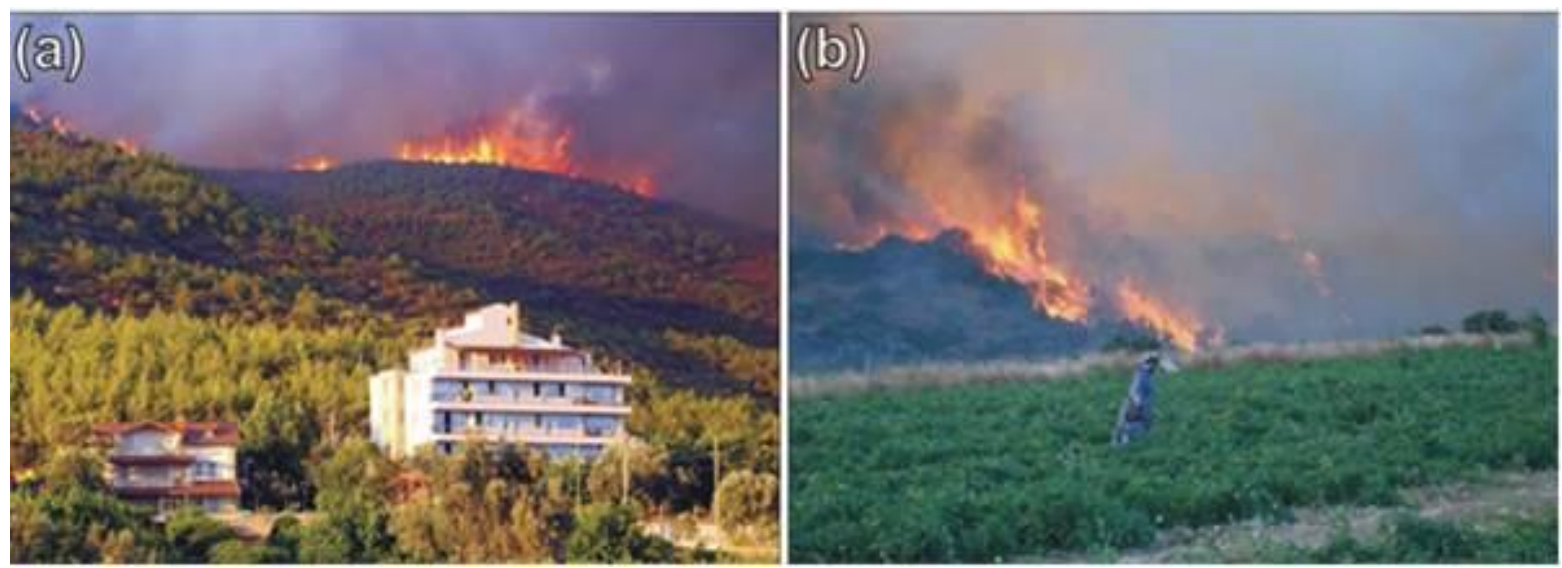

Şekil 4. (a) 23 Ağustos 2011 günü İzmir Seferihisar'da 352 ha (Anonim, 2013d) ve (b) 18 Ağustos 2011 günü Çanakkale Bayramiç’te 168 ha (Anonim, 2013e) orman alanının zarar görmesine neden olan orman yanginları.

2011 yılında en fazla yangın sayısına sahip Muğla dışında, İstanbul, Antalya, İzmir ve Adana 100'den fazla orman yangını görülen OBM’leri oluşturur (Şekil 3a). Yanan alanlar açısından İzmir’i Balıkesir OBM (Şekil 4b), 421 ha yanan alan ile izlerken, Muğla, Mersin, Bursa, Amasya, Ankara, Adana, Adapazarı, Denizli, Isparta, Kahramanmaraş ve Kayseri gibi çok sayıda bölge müdürlüğ̈nde 100 hektardan daha fazla orman alanı yangınlarda zarar gördü (Şekil 3b).

2011 yılında Türkiye'de oluşan orman yangınlarının Karadeniz kıyı kuşağı dışında kalan öteki kıyılardaki bölge müdürlüklerinde yoğunlaştığı görülür. Adana, Kahramanmaraş, Balıkesir ve Ankara OBM’lerinde, çok sayıda orman yangını çıkmamakla birlikte, yanan alanların genişliği 100 hektarın üzerindedir (Şekil 3).

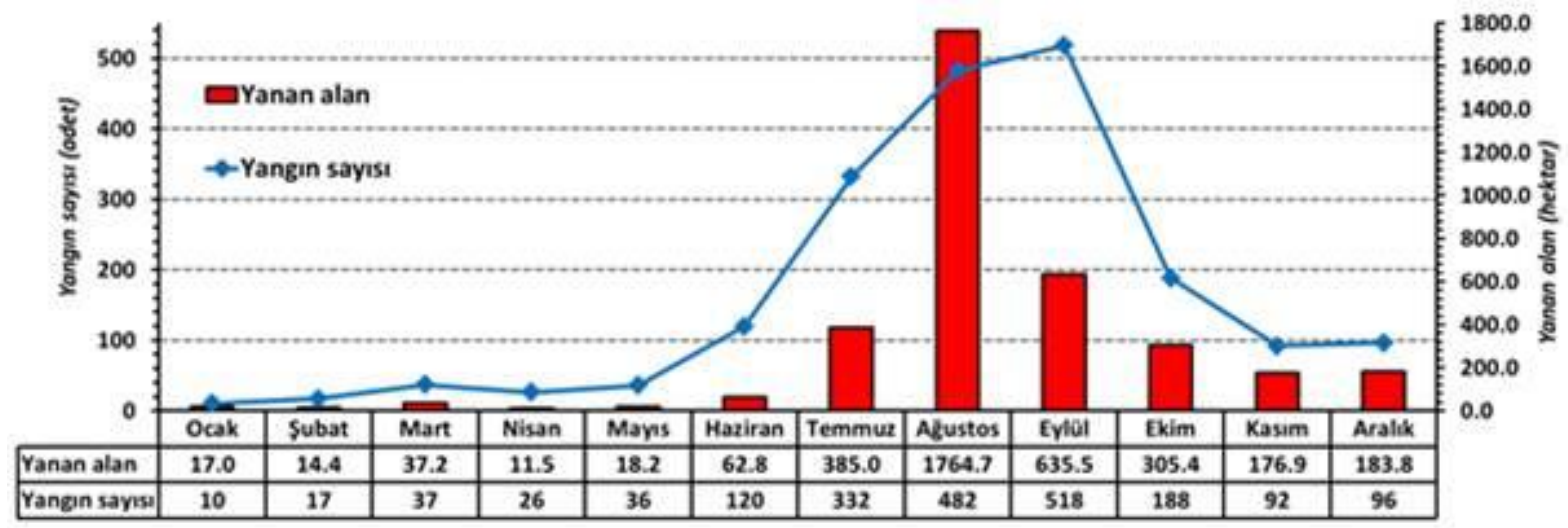

Şekil 5. Türkiye'de 2011 yılında oluşan orman yangınlarının ve yanan alanların aylara göre dağılışı.

2011 yılı orman yangınlarının aylara göre dağılımında ise, oluşan yangınların büyük çoğunluğunun Eylül ayında çıktığı görülür. 518 orman yangınının oluştuğu bu ayı Ağustos takip ederken Temmuz ayı da üçüncü en fazla yangının oluştuğu ay olmuştur. 2011 yılında yanan alanların en fazla olduğu ay ise yaklaşık olarak 1765 ha orman alanının zarar gördüğü Ağustos ayıdır. Eylül ayı 635 ha ile Ağustos ayından sonra en fazla orman alanının zarar gördüğü ikinci ayı 
Türkeș, M., \& Altan, G. (2014). Türkiye'de 2011'de olușan orman yangınlarının klimatolojik çözümlemesi ve hidroklimatik, yüzey hava ve yüksek atmosfer koşullanı ile bağlantiları. International Journal of Human Sciences, 11(1), 145-176.

oluştururken, Temmuz ve Ekim ayları 300 hektardan daha fazla ormanlık alanın zarar gördüğü öteki aylar olmuştur (Şekil 5).

(a) Yangın sayısı (\%)

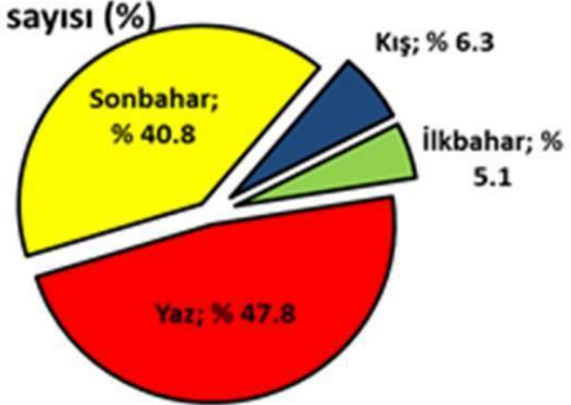

(b) Yanan alan (\%)

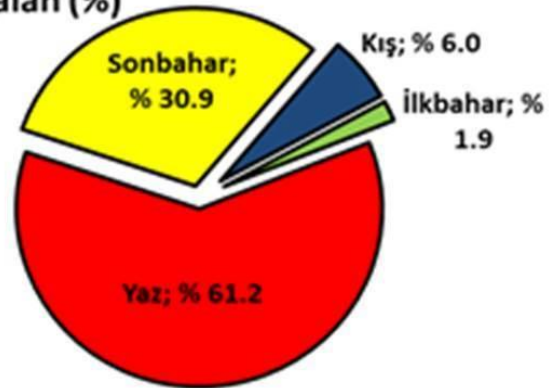

Şekil 6. 2011 yılında Türkiye'de oluşan orman yangınları ve yanan alanların mevsimlere göre dağılıșı (\%).

Türkiye'de 2011 yılında oluşan orman yangınlarının yarısına yakını yaz aylarında oluşurken, en fazla yangının görüldüğü ikinci mevsim sonbahardır. En az orman yangını çıkan ilkbahar mevsiminde, Aralık, Ocak ve Şubat aylarından bile daha az sayıda orman yangını oluşmuştur (Şekil 6a). 2011 yılında yanan alanların mevsimlere dağılışında ise yangın sayısında olduğu gibi, yaz mevsiminin büyük bir orana sahip olduğu görülür. Sonbahardaki orman yangınlarında meydana gelen kayıplar yil boyunca yanan alanların \% 30’unu oluştururken yangın sayısında en düşük orana sahip olan ilkbahar mevsimi, yanan alanlar arasında da en düşük orana sahiptir (Şekil 6b).

\subsection{Y11 Keetch-Byram Kuraklık İndisi Sonuçları}

Türkiye'de 2011 yllının ilk 5 ayında kuraklık indisi aylık ortalamaları tüm istasyonlarda 100 değerinin altında kalmıştır. Türkiye ikliminin özellikle yağış ve sıcaklık rejiminin bilinen doğal bir sonucu olarak, 2011 yılının Haziran ayına kadar süren 1lık/soğuk ve nemli/yağışlı koşullar orman yangın risk olasılı̆ıının yüksek olmasını engeller. Bu 5 aylık dönemde kuraklık indisi, Mayıs ayında ve yalnız Muğla ile Antakya istasyonlarında 100 değerine yaklaşmış ve 124 orman yangınında yaklaşık 100 ha orman alanı kaybedilmiştir (Şekil 7).

Türkiye'de Mayıs ayından başlayarak, karasal iç ve doğu bölgeler dışında genel olarak yağışlar azalır; bu durum özellikle yağışların çok ender olduğu ya da hemen hiç yağmadı̆̆ı Akdeniz ikliminin egemen olduğu Türkiye'nin batı ve güney bölgelerinde daha belirgindir. Buna ek olarak, hava (gece ve gündüz) sıcaklıklarının hızla yükselmesiyle bağlantılı olarak artış gösteren kuraklık indisi Haziran'da 100’lü değerlere ulaşarak, Türkiye'nin batı ve güneyinde yer alan OBM’lerde yangın olasıllğını yok düzeyinden düşük düzeyine yükseltir. Şanlıurfa OBM'de bu aydan başlayarak yangın olasılığının öteki OBM'lere göre daha fazla artış göstererek orta düzeye çıkması, burada kuraklık etkisinin daha şiddetli belirmesiyle ilgilidir (Şekil 7). 
Türkeș, M., \& Altan, G. (2014). Türkiye'de 2011'de olușan orman yangınlarının klimatolojik çözümlemesi ve hidroklimatik, yüzey hava ve yüksek atmosfer koşulları ile bağlantilar1. International Journal of Human Sciences, 11(1), 145-176.

\section{(a) Haziran}

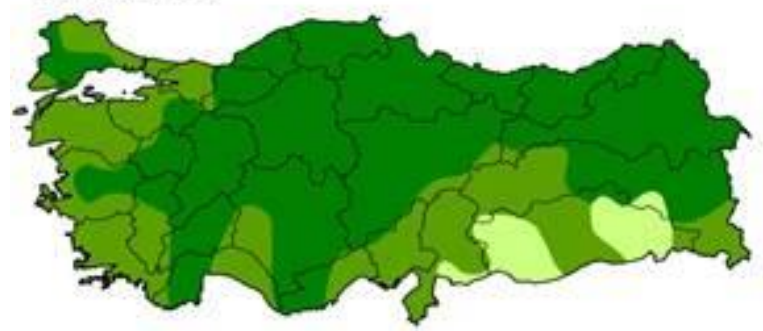

(c) Ağustos

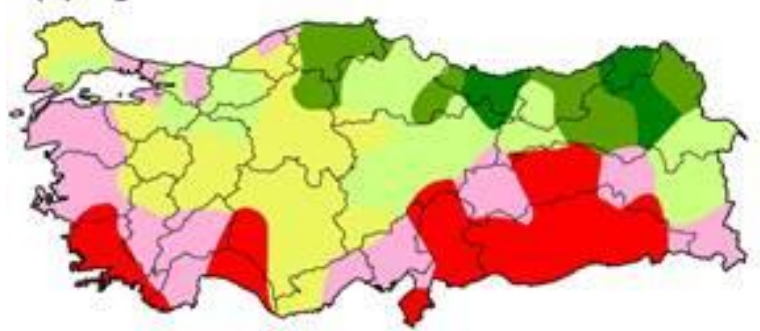

(e) Ekim

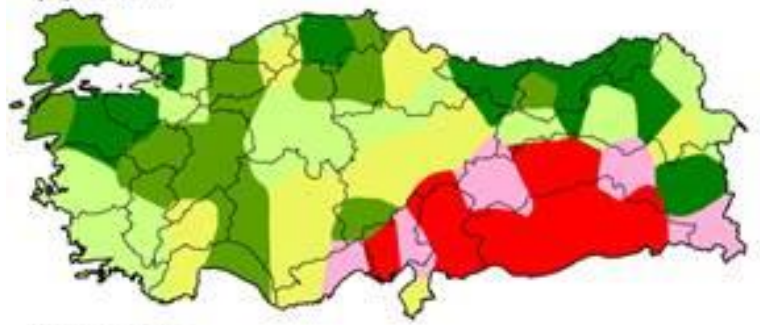

(g) Aralık

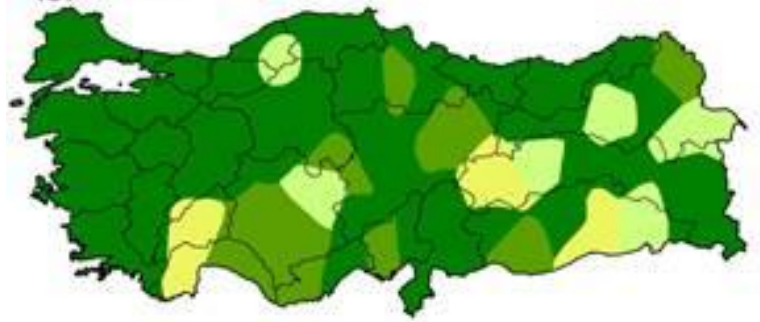

(b) Temmuz

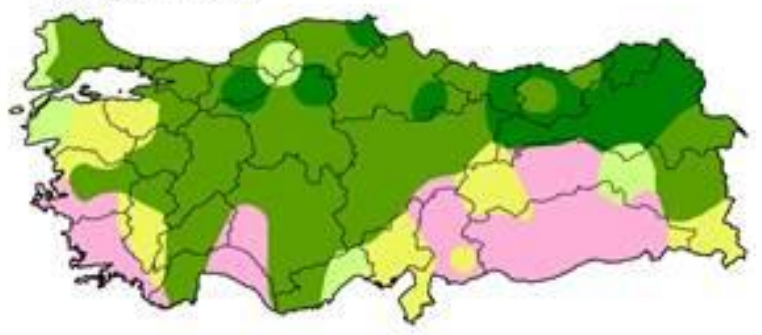

(d) Eylül

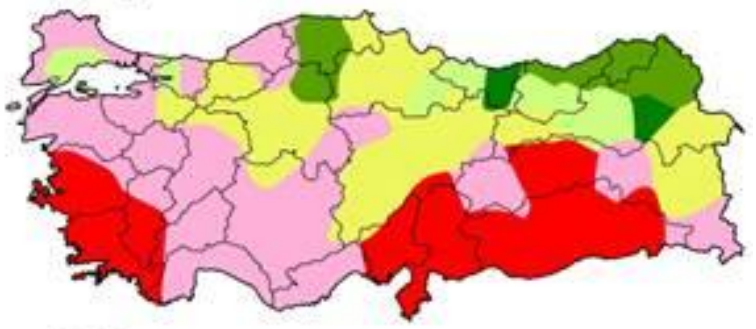

(f) Kasım

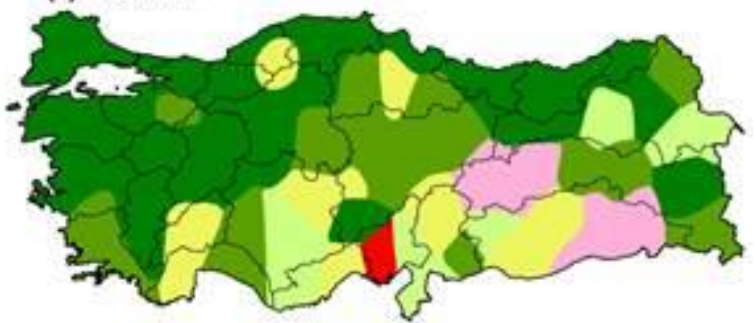

(h) Yillık

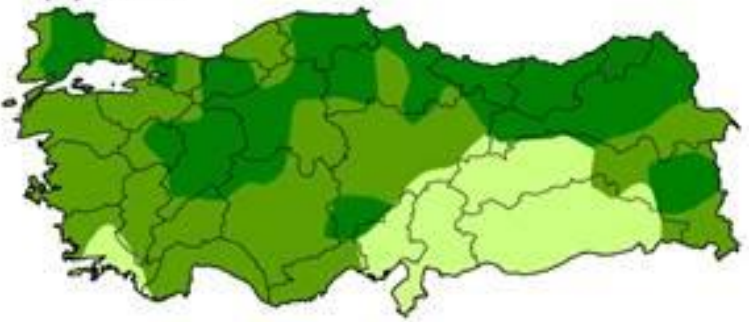

Yangın olasılığı yok

Yangın olasıı̆̋̆ı orta

Yangın olasılığı düşük Yangın olasılığı yüksek

Yangın olasıliğı oldukça yüksek

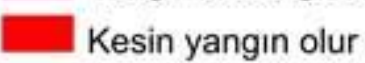

Şekil 7. 2011 yılı Keetch-Byram Kuraklık İndisi değerlerinin, orman yangını çıkmış olan aylardaki aylık ve yıllık ortalama değerlerinin Türkiye üzerindeki alansal dağıllş desenleri.

Türkiye'de 2011 yllının Temmuz ayı kuraklık indisine göre, Şanlıurfa, Kahramanmaraş, Elazığ, Antalya, Muğla ve İzmir OBM’lere bağlı alanlarda yangın olasıllğı oldukça yüksek düzeydedir. Temmuz ayında kuraklık indisindeki bu artışın temel nedenleri, yağışların Haziran ayından başlayarak azalması ve maksimum sıcaklıklarda gözlenen ciddi artışlardır. Buna bağlı olarak, bu dönemde kuraklık indisi pek çok istasyonda 400-600 değerleri arasında gerçekleşmiş ve çıkan 332 orman yangınında 385 ha orman alanının zarar görmesine ve/ya da yok olmasina neden olmuştur. (Şekil 5 ve 7b).

Ağustos ayında ise, yangın olasılığı 2011 yllında ilk kez kesin yangın olur düzeyine kadar yükselmiştir (Şekil 7c). Şanlıurfa'dan başlayarak, Kahramanmaraş OBM’nin Hatay bölümü, Elazı̆̆ 
Türkeş, M., \& Altan, G. (2014). Türkiye'de 2011'de oluşan orman yangınlarının klimatolojik çözümlemesi ve hidroklimatik, yüzey hava ve yüksek atmosfer koşulları ile bağlantilar1. International Journal of Human Sciences, 11(1), 145-176.

OBM'nin orta kesimleri, Antalya OBM'nin doğu ve Muğla OBM’nin tümü yangın olasıllı̆̆ının en yüksek olduğu alanlara karşılık gelir. Konya OBM’nin Antalya OBM sınırında yangın olasılığ1 kesin yangın olur düzeyindeyken, İstanbul, Kocaeli, Balıkesir, İzmir, Mersin ve Adana kıyıları ile Elazığ OBM içerisinde kalan alanların büyük bölümünde yangın olasıllğ̆1 oldukça yüksek düzeydedir. Bu ayda oluşan 482 orman yangınında, 1764 ha ile 2011 yllında bir ayda en fazla yanan orman alanı görülmektedir (Şekil 5).

Eylül kuraklık indislerine göre, kesin yangın olur düzeyinin yayılış alanları biraz daha genişleyerek İzmir, Adana ve Kahramanmaraş OBM’lerdeki bazı bölümleri de içerisine alır (Şekil 7d). İç-batı Anadolu ile İç Anadolu bölgelerindeki OBM’lerin çoğunluğunda, yang1n olasıllı̆̆1 oldukça yüksek düzeye yükselir. Doğu Karadeniz bölümü dışında kalan Karadeniz kıyılarındaki bölge müdürlüklerinin bazılarında bile, yangın olasılığı yüksek ve oldukça yüksek düzeylere çıkar. Ağustos ayına oranla Denizli OBM'de de kuraklık etkisi şiddetlenerek, daha fazla orman yangını oluşturma potansiyeline sahip olmaya başlar. 2011 yllinda kuraklık etkisinin bu kadar şiddetli hissedildiği Eylül ayında, Türkiye'deki en fazla orman yangın sayısı olan 518 orman yangınına ulaşılırken, 635 ha orman arazisinin çıkan yangınlardan etkilendiği görülür (Şekil 5).

Ekim ayında, kuraklık indisinin en yüksek düzeyi Şanlıurfa ve Kahramanmaraş OBM'lerde daha belirgin olmak üzere, Adana ve Elazığ’’ın bir bölümünde görülür. Güneydoğu Anadolu Bölgesi'nin genelinde kesin yangın olur düzeyinin dışında kalan OBM’ler, yangın olasıllğıının oldukça yüksek olduğu düzeydedir (Şekil 7e). İç bölgelerde yangın olasıllı̆ının azalmaya başladığı, kıyı kesimlerde bulunan bölge müdürlüklerinde ise, yağışların artmaya başlamasıyla birlikte kurak koşulların azalması ve yangın olasılığının da düşmesi söz konusu olur. Bu ay içerisinde görülen 188 orman yangınındaki 305 hektarlık orman kaybı da, bir önceki aya göre yangın sayısında yaklaşık üç kat, yanan alanda ise iki kat azalmanın nedenini açıklamaktadır (Şekil 5).

Kasım ayında nemli koşulların etkili olmaya başlamasına rağmen, yangın olasılığının oldukça yüksek ve kesin yangın olur düzeylerinde olduğu bölge müdürlüklerine rastlamak dikkat çekicidir. Şanlıurfa OBM'nin doğu, Elazığ OBM'nin batı kesimleri oldukça yüksek, buna karşılık Adana OBM'nin batı kesimleri ise kesin yangın olur düzeylerindedir (Şekil 7f). Artan yağışlara ve azalan hava sıcaklıklarına bağlı olarak bağıl nemin de artış gösterdiği, toprak su açığının giderek tamamlanmaya başladığı bu ayda, sözü edilen OBM’lerde kuraklık etkisinin halen devam etmesi bu yörelerdeki yerel kuraklık olayları ve görece sıcak ve kuru koşulların belirmesini sağlayan mikroklima (sahip olduğu fiə̧iki coğrafya koşullarn ve etmenleri nedeniyle iklim açısından da çevresinden ayrlan kü̧̈ük ya da yöresel iklim) koşulları ile bağlantılı olabilir. Türkiye genelinde ise sözü edilen bölge müdürlüklerine göre daha nemli koşullar egemenken, Kasım ayında 92 orman yangınında yaklaşık 177 ha orman alanı zarar görmüştür (Şekil 5). 2011 yllı Aralık ayı Türkiye genelinde nemli 
Türkeş, M., \& Altan, G. (2014). Türkiye'de 2011'de oluşan orman yangınlarının klimatolojik çözümlemesi ve hidroklimatik, yüzey hava ve yüksek atmosfer koşulları ile bağlantilar1. International Journal of Human Sciences, 11(1), 145-176.

koşulların egemen olduğu aylardan biridir. Yangın olasılı̆̆1 en fazla yüksek düzeyde bulunurken, haritanın büyük bölümünde nemli koşulların etkisiyle yeşil renklerin daha geniş alanlar kapladığı görülür. Yangın olasıllğg bu ayda yok, düşük ve orta düzeyler ile yüksek düzeylerde bulunur (Şekil $7 \mathrm{~g}$ ). Öte yandan, Aralık ayında bile 96 orman yangınının çıkması ve bu yangınlarda yaklaşık 184 ha orman alanının zarar görmüş olması (Şekil 5), düşündürücüdür.

2011 yıllık ortalama KBDI değerlerinin dağılışında ise, aylık dağılışlardan farklı olarak yangın olasılıklarının (Haziran ayı hariç) daha düşük değerlere sahip olduğu görülür. Bu durum üzerinde etkili olan en önemli etmen yıl içinde yağışı aylarda alınan toplam yağışın, az yağışsı ya da yağışsız dönemlerdeki kuraklık etkisini dengelemesidir (Türkeş ve ark., 2012). Bu yüzden, Türkiye'nin büyük bölümünde yıllık ortalama haritasında en yüksek yangın olasıllı̆ğını orta düzeyde kalmasına neden olur. Türkiye'nin kuzey bölümleri Karadeniz’in nemli-1lıman iklim özelliklerini yansıtırken, Artvin, Trabzon, Giresun, Amasya'nın bir bölümü, Kastamonu ve Bolu yangın olasıllı̆̆ının en düşük olduğu OBM’lerdir (Şekil 7h). Buna karşılık Güneydoğu Anadolu'da Şanlıurfa, Kahramanmaraş, Adana ve Elazı̆̆ orman bölge müdürlükleri, yangın olasıllğının yıllık ortalamalarda en yüksek düzeyde olduğu alanlardır. Yangın olasıllğının orta düzeyde olduğu bu bölge müdürlüklerinde yl boyunca oluşan 214 orman yangınında 565 ha orman alanı zarar görmüştür. Yıllık ortalamalarda yangın olasıllğının orta düzeyde olduğu bir başka bölge müdürlüğü Muğla'da ise, y1l boyunca sözü edilen bu 4 OBM'den daha fazla sayıda yangın çıkmış ve oluşan 267 orman yangınında 165 ha orman alanı yanmıştır (Türkeş ve ark., 2012).
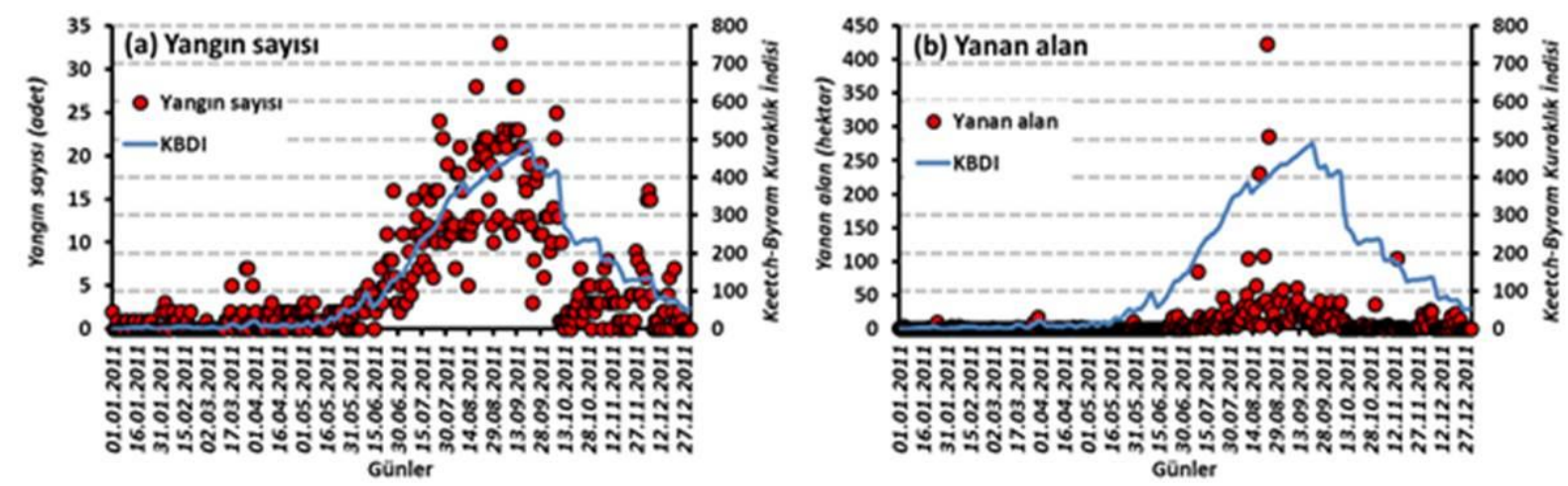

Şekil 8. Seçilen 75 meteoroloji istasyonunun 2011 yll verilerine uygulanan Keetch-Byram Kuraklık İndisi değerleri ve Türkiye'de 2011 yllında oluşan (a) orman yangınları ile (b) yanan alanlar arasındaki ilişkilerin yılın günlerine göre karşılaştırılması.

\subsection{Keetch-Byram Kuraklık İndisi'nin 2011 yı1ı Orman Yangınlarını Yakalama Oranları}

Bu bölümde, 2011 y1lında Türkiye'de oluşan orman yangınları ile Keetch-Byram Kuraklık İndisi’nin orman yangınlarını ve yanan alanları yakalama oranları karşılaştırıldı (Şekil 8 ve 9). 2011 yılına ait günlük yangınlar ve yanan alanlar Türkiye için seçilen 75 meteoroloji istasyonunun ortalama verilerine bağlı olarak çakıştırıldı. 2011 yılı verileri kullanılarak hesaplaması yapılan 
Türkeș, M., \& Altan, G. (2014). Türkiye'de 2011'de olușan orman yangınlarının klimatolojik çözümlemesi ve hidroklimatik, yüzey hava ve yüksek atmosfer koşulları ile bağlantilar1. International Journal of Human Sciences, 11(1), 145-176.

KBDI ile Türkiye'de 2011 yılında oluşan orman yangınlarının karşılaştırmasına göre, 2011 yılında Türkiye'de oluşan orman yangınlarıyla KBDI hesaplamaları arasında özellikle yaz ve sonbahar aylarında iyi bir ilişkinin varlığından söz edilebilir (Şekil 8 ve 9).

75 meteoroloji istasyonunun ortalama verilerinden hesaplanan kuraklık indisi eğrisi, 2011 yılı Haziran ayı son haftasına kadar yangın olasılığının olmadığı düzeydedir (Şekil 8). Bu dönemde oluşan 214 orman yangınında 186 ha orman alanı zarar gördü. Haziran sonu ve Temmuz ayının ilk haftasında kuraklık indisi yangın olasılığını arttırarak düşük düzeye yükseltir. Yangın olasılı̆̆ının görece düşük olduğu bu dönemde 272 orman yangını 442 ha orman alanını olumsuz etkilemiştir (Şekil 8).

Temmuz ayının sonundan başlayarak yangın olasıllğı yüksek düzeye çıkarken, bu durum yaklaşık 1 ay boyunca Ağustos ayının son haftasına kadar devam eder. Bu dönemde oluşan 409 orman yangını 1370 ha orman alanını olumsuz etkiler (Şekil 8). Ağustosun son haftasından Ekim ayının ilk on gününe kadarki 47 gün boyunca, yangın olasıllğı oldukça yüksek bir düzeye yükselmiştir. Bu dönemdeki 787 orman yangınında 1310 ha orman alanı zarar gördü. Ekim ayının ortasından başlayarak yılın sonuna kadar yangın olasıllğı artan yăğşlarla birlikte sürekli olarak düşüş gösterdi ve bu 2.5 aylık dönemde oluşan 244 orman yangını 452 ha genişliğinde orman kaybına neden oldu (Şekil 8).
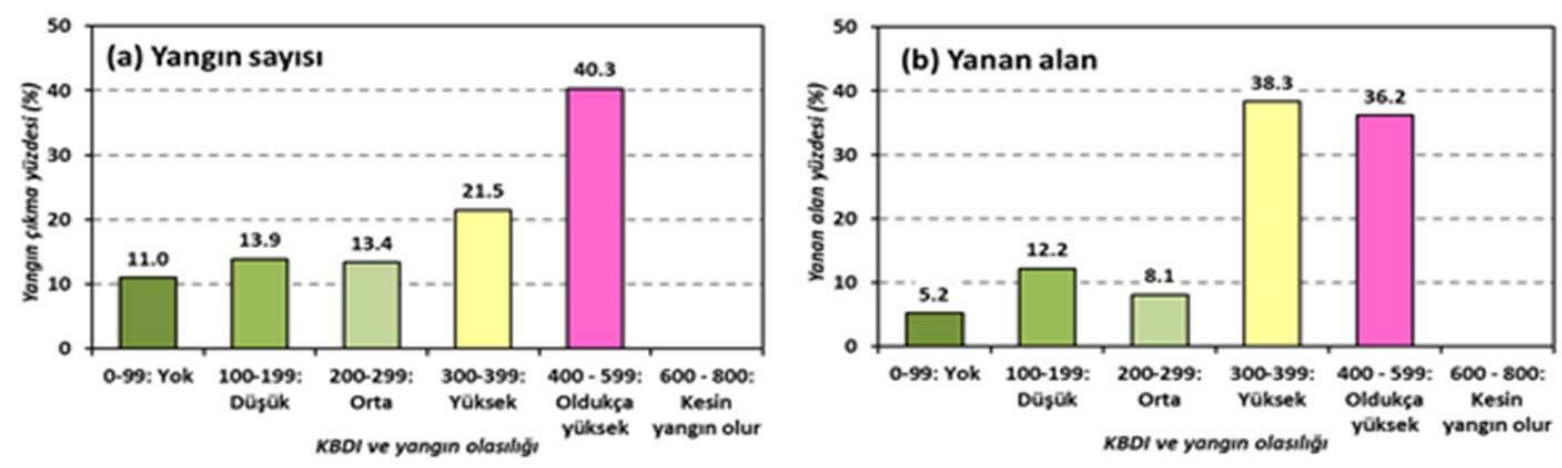

Şekil 9. KBDI'nin 2011 yilında Türkiye'deki (a) yang1n, (b) yanan alan yakalama oranları.

2011 yılı hesaplamalarına göre, KBDI kesin yangın olur düzeyine ulaşmadığından bu düzeyde orman yangını ve yanan alan meydana gelmedi. Buna göre yapılan değerlendirmede yanan alan ve yangın sayısında kesin yangin olur düzeyinin oranı \% 0 olduğundan, yangın ve yanan alan yakalama oranlarında öteki 5 sınıfın oranları \% 100 üzerinden ele alındı (Şekil 9). Yangın yakalama oranlarında en fazla yangının oluştuğu sınıf oldukça yüksek düzey olurken, 1954 orman yangınının yarısına yakını bu düzeyde meydana geldi. Yangın olasılığının yüksek olduğu düzey (\% 21 ile) en fazla yang1nı yakalayan ikinci düzey olurken, yangın olasılığının yok, düşük ve orta olduğu düzeyler ise toplamda \% 38 orana sahiptir (Şekil 9a). 
Türkeş, M., \& Altan, G. (2014). Türkiye'de 2011'de oluşan orman yangınlarının klimatolojik çözümlemesi ve hidroklimatik, yüzey hava ve yüksek atmosfer koşulları ile bağlantilar1. International Journal of Human Sciences, 11(1), 145-176.

Yangın olaylarının (yangın sayısı ve alanı) en fazla yakalandığı sınıf, yangın olasılı̆̆ının yüksek olduğu düzeydir. Bu düzeyde yanan alanların \% 38’i KBDI tarafindan yakalanırken, \% 36 ile yangın olasılığının oldukça yüksek olduğu düzey ikinci en fazla yanan alanı yakalayan düzey oldu. Ayrıca, yangın olasılığının yok, düşük ve orta olduğu düzeylerin toplamı, yanan alanların \% 25’ine karşılık gelir. 2011 yılında yanan alanların yaklaşık olarak \% 75'i yangın olasıllığının yüksek ve oldukça yüksek olduğu düzeylerde yakalamıştır. Bu oranla kesin yangın olur düzeyinde yanan alan yakalamamış olmakla birlikte, indisin yüksek ve oldukça yüksek olduğu düzeylerde önemli oranlarda yanan alanları yakalaması yüksek bir ilişkinin varlığını gösterir (Şekil 9b).

\subsection{Yılı Büyük Orman Yangınlarının Klimatolojik ve Meteorolojik Bağlantıları}

Makalenin bu bölümünde, yangın sayısı ve yanan alanın genişliği açısından Türkiye'de 2011 yılında kaydedilen büyük orman yangınlarının olası klimatolojik ve meteorolojik nedenleri tartışıldı ve bireştirildi. Bu amaçla, çoğunlukla NOAA/ESRL Fiziksel Bilimler Bölümü hava ve iklim veri tabanı ve harita analiz olanakların1 (www.esrl.noaa.gov/psd/psd1/) kullanarak, Türkiye'yi de içerecek biçimde en geniş şekliyle Akdeniz Havzası'nın en kurak, en sıcak ve orman yangınlarından en fazla etkilendiği ve etkilenebilirliğin en yüksek (örn. Kuraklık ve KBDI en yüksek düzeylerinde) olduğu 2011 yaz mevsimi ve Ağustos ayı ile 17-18 Ağustos 2011 ve 1-2 eylül 2011 günleri için hazırlanan aylık, mevsimlik, günlük ortalama ve 1951-2010 dönemi klimatolojisine göre anomali, hidroklimatoloji, yüzey hava ve yüksek atmosfer haritalarının sinoptik klimatolojik ve meteorolojik çözümlemeleri yapıldı (Şekil 10, 11, 12, 13, 14, 15).

\subsubsection{1 yazında Akdeniz Havzası'nı ve Türkiye'yi etkileyen hidroklimatolojik ve sinoptik klimatolojik koşullar}

2011 yaz mevsimi yağış toplamlarının (mm) dağılış deseni (Şekil 10a), uzun süreli ortalama toplam yağış tutarlarının büyüklük ve dağıllş desenine benzer bir biçimde (örn. Türkeş, 1998, 2003, 2010, vb.), Karadeniz Bölgesi ve Kuzeydoğu Anadolu Bölümü’nün en yüksek yağiş toplamlarını alırken, genel olarak Akdeniz ikliminin egemen olduğu Anadolu Yarımadası'nın batı ve güney bölgelerinin 20 mm'nin altında, Ege ve Akdeniz kıyı kuşağı ve Güneydoğu Anadolu'nun Suriye sınırına yakın bölümünün 10 mm'nin altında ve sıfıra yakın yağış aldığını gösterir. Uzun süreli ortalamayla karşılaştırıldığındaysa, 2011 yaz mevsiminin genel olarak Türkiye'nin batısındaki bölgelerin, özellikle Marmara ve Batı Karadeniz'de daha az yağışı (kurak) olduğu görülür (Şekil 10b).

Yaz mevsimi günlük yağış toplamları (yağış oranı, mm/gün) incelendiğindeyse, mevsimlik toplam yağış desenine benzer bir desenin varlığ1 görülür (Şekil 10c). Buna göre, Türkiye'nin hemen tamamında yağış oranı uzun süreli ortalamaya göre önemli bir değişim göstermez (Şekil 
Türkeş, M., \& Altan, G. (2014). Türkiye'de 2011'de oluşan orman yangınlarının klimatolojik çözümlemesi ve hidroklimatik, yüzey hava ve yüksek atmosfer koşulları ile bağlantilar1. International Journal of Human Sciences, 11(1), 145-176.

10d). Başka bir deyişle, 2011 yazı günlük yağışlar açısından da, Akdeniz ikliminin iyi bilinen doğal bir özelliği olan yaz kuraklığ1 (klimatoloji) ile tutarlı olarak çok kurak geçmiştir. Bu durum, özellikle Ege, Akdeniz ve Güneydoğu Anadolu bölgelerinde çok belirgindir (Şekil 10d).
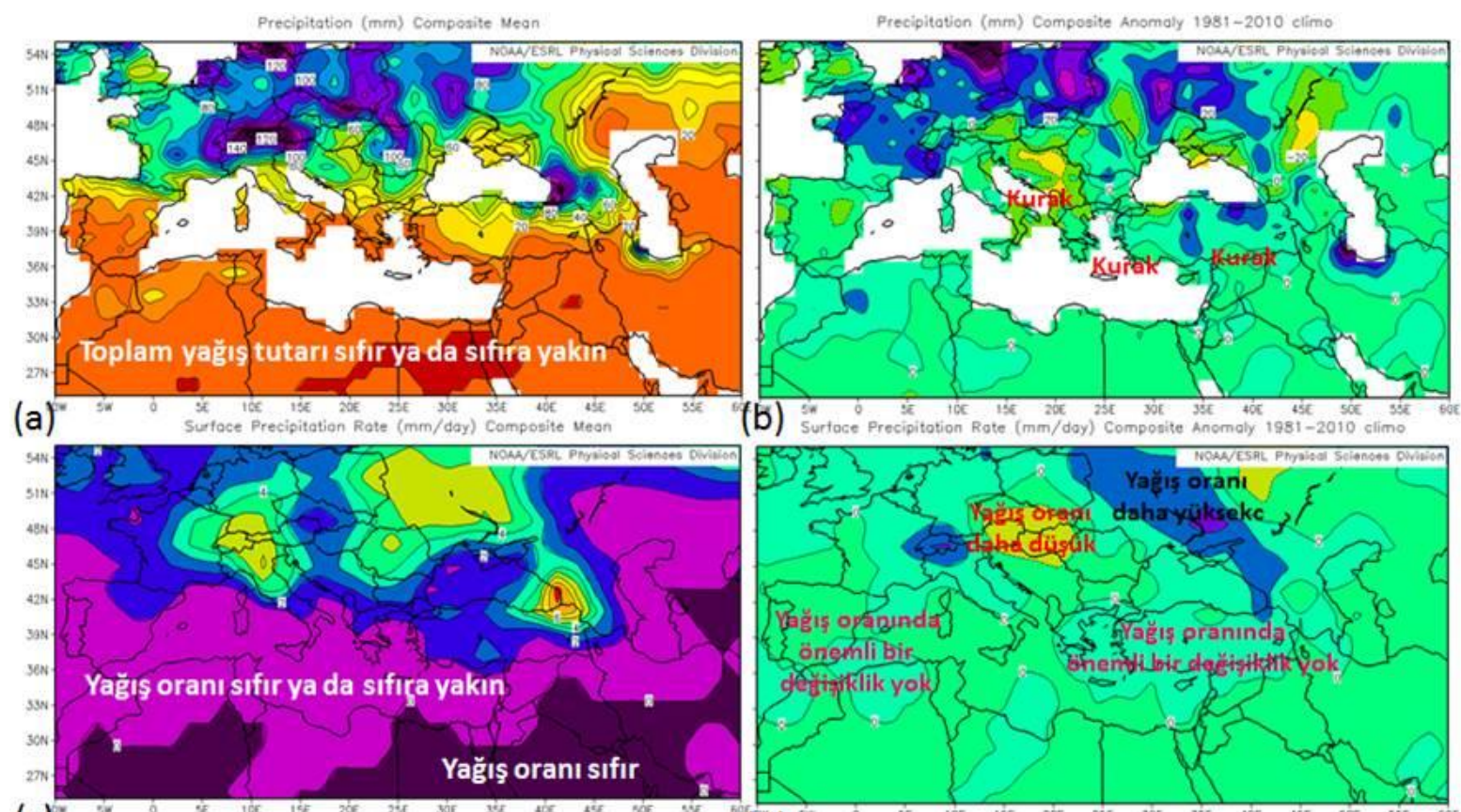

(c)
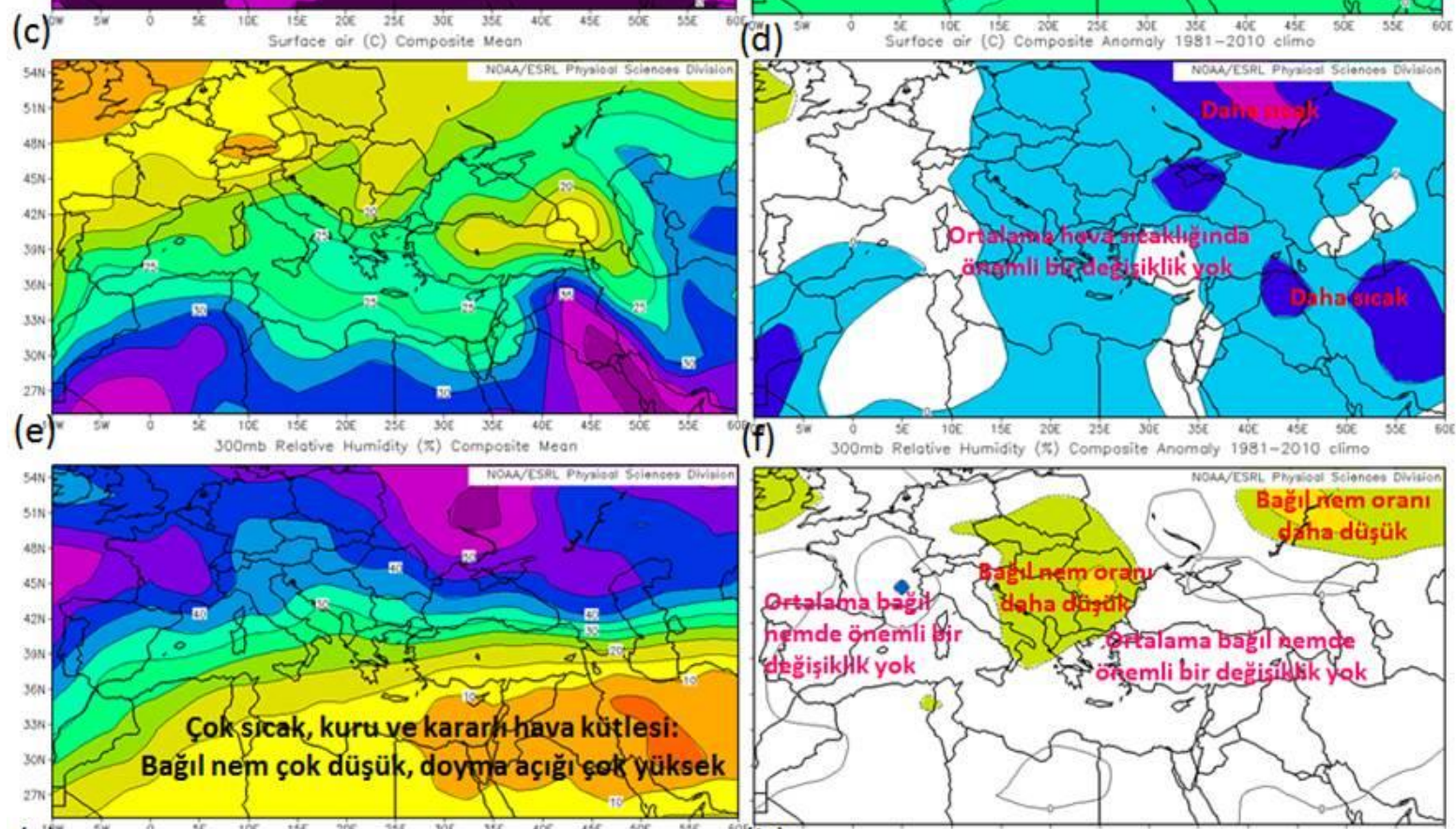

(g)

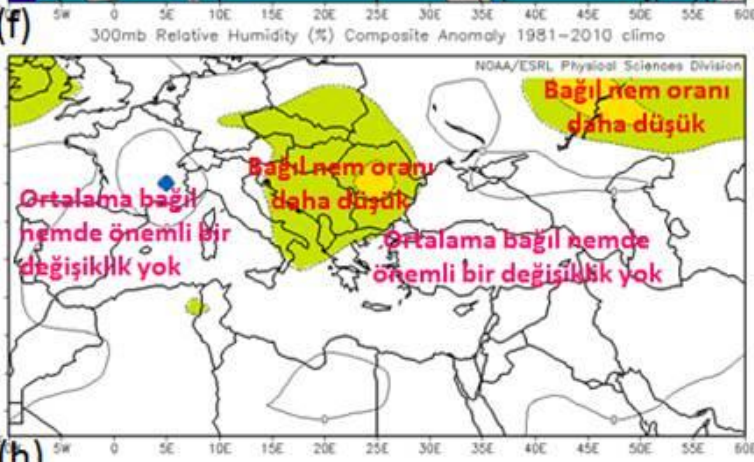

Şekil 10. Çoğunlukla NOAA/ESRL/PSD - NCEP/NCAR yeniden çözümleme veri tabanına dayanarak, 2011 yaz mevsimi (Haziran, Temmuz, Ağustos), (a) birleşik ortalama toplam yağış tutarı (mm) ve (b) 1951-2010 dönemi klimatolojisine göre anomalisi (mm); (c) birleşik ortalama yüzey yağış oranı (mm/gün) ve (d) anomalisi (mm/gün); (e) birleşik ortalama yüzey hava sıcaklığ1 $\left({ }^{\circ} \mathrm{C}\right.$ ) ve (f) anomalisi $\left({ }^{\circ} \mathrm{C}\right) ;(\mathrm{g}) 1000 \mathrm{hPa}-300 \mathrm{hPa}$ kalınlığında birleşik ortalama atmosferik dikine bağıl nem $(\%)$ ve (h) anomalisinin (\%) geniş Akdeniz Havzası üzerindeki alansal dağıllş desenleri.

2011 yazı, uzun süreli ortalamalarla uyumlu olarak, Türkiye’nin Karadeniz Bölgesi ile İç ve Doğu Anadolu bölgelerinin kuzey bölümlerinde görece serin, Akdeniz ve Güneydoğu Anadolu 
Türkeș, M., \& Altan, G. (2014). Türkiye'de 2011'de olușan orman yangınlarının klimatolojik çözümlemesi ve hidroklimatik, yüzey hava ve yüksek atmosfer koşulları ile bağlantilar1. International Journal of Human Sciences, 11(1), 145-176.

bölgelerindeyse en yüksek sıcaklıkların egemen olduğu bir desen sergiler (Şekil 10ef). 2011 yaz mevsimi, uzun süreli ortalamaya göre, genel olarak $\pm 1^{\circ} \mathrm{C}$ arasında değişen zayıf bir anomali deseni ile nitelenir. 2011 yazı, uzun süreli ortalamalarla uyumlu olarak, Türkiye’nin Karadeniz Bölgesi ile İç ve Doğu Anadolu bölgelerinin kuzey bölümlerinde görece serin, Akdeniz ve Güneydoğu Anadolu bölgelerindeyse en yüksek sıcaklıkların egemen olduğu bir desen gösterir (Şekil 10f).

Önceki yaz haritalarının sunduğu bilgilerin yanı sıra, yaz mevsimi ortalama 1000 hPa-300 hPa atmosfer kalınlığı bağıl nem (\%) dağılış deseni (Şekil 10g), Türkiye’nin güney yarısı, Kuzey Afrika, Orta ve Batı Akdeniz ve Orta Doğu (Mezopotamya) bölgelerinin, çok sıcak, kuru, kararlı ve bu yüzden yağış olasıllğı çok düşük karasal tropikal (cTWs) hava kütlesiyle, genel olarak Akdeniz Havzası ve Türkiye'nin kuzeyindeki bölgelerinse değişmiş (modifikasyona uğramış) kararlı denizel tropikal (mTWs) ve kaynak bölgesi nedeniyle 1lık ve kararsız denizel polar (mPCu) hava kütleleriyle (Türkeş, 1998, 2010) kaplandığını gösterir. Orta Avrupa ve Balkanlar'da bağıl nem oranı uzun süreli ortalamadan daha düşüktür; Türkiye'de ise önemli bir değişiklik görülmez (Şekil 10h). Sonuç olarak, Türkiye ve bölgesinin genel klimatolojik özelliklerine ek olarak, buraya kadar açıklanan hidroklimatolojik ve meteorolojik koşulların, 2011 yazında Türkiye ormanlarında büyük orman yangını üretme risk potansiyelinin yüksek olduğu söylenebilir.

\subsubsection{Ağustos 2011'de Akdeniz Havzası'nı ve Türkiye'yi etkileyen hidroklimatolojik, sinoptik klimatolojik ve meteorolojik koşullar}

Ağustos, orman yangınları açısından hem yaz mevsimini en iyi temsil eden ay olduğu, hem de 2011 yazında çıkan büyük orman yangınlarının çoğu bu ayda kaydedildiği için, yaz mevsiminden ayrı ve ayrıntılı olarak incelendi. Ağustos yaz mevsimini egemen hava ve iklim koşulları açısından en iyi temsil eden ay olduğu için, 2011 Ağustos sonuçları da genel olarak 2011 yaz sonuçlarına benzemektedir (Şekil 11).

2011 Ağustos toplam yağış tutarları, Akdeniz Havzası'nın Güney Avrupa bölümü ve Türkiye'nin Karadeniz Bölgesi, doğu Marmara ve Kuzeydoğu Anadolu bölümleri dışında kalan alanlarda sıfır ya da sıfır dolayındadır (Şekil 11a). Ağustos, Batı Karadeniz’in bir bölümü, Ankara ve Trabzon yöreleri dışında kalan yerlerde, uzun süreli ortalamaya göre de daha kurak geçmiştir (Şekil 11b). Öte yandan, Karadeniz Bölgesi ve Doğu Anadolu'nun kuzeyi dışında Türkiye’nin büyük bir bölümünde, yağış oranı sıfir ya da sıfıra yakınken (Şekil 11c), uzun süreli ortalamaya göre Doğu Anadolu ve Doğu Karadeniz dışında yağış oranında önemli bir değişim görülmez (Şekil 11d). 
Türkeș, M., \& Altan, G. (2014). Türkiye'de 2011'de olușan orman yangınlarının klimatolojik çözümlemesi ve hidroklimatik, yüzey hava ve yüksek atmosfer koşulları ile bağlantilar1. International Journal of Human Sciences, 11(1), 145-176.

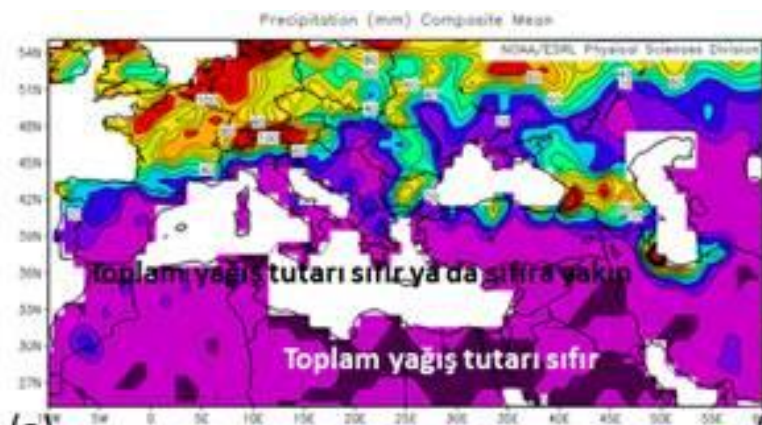

(a)
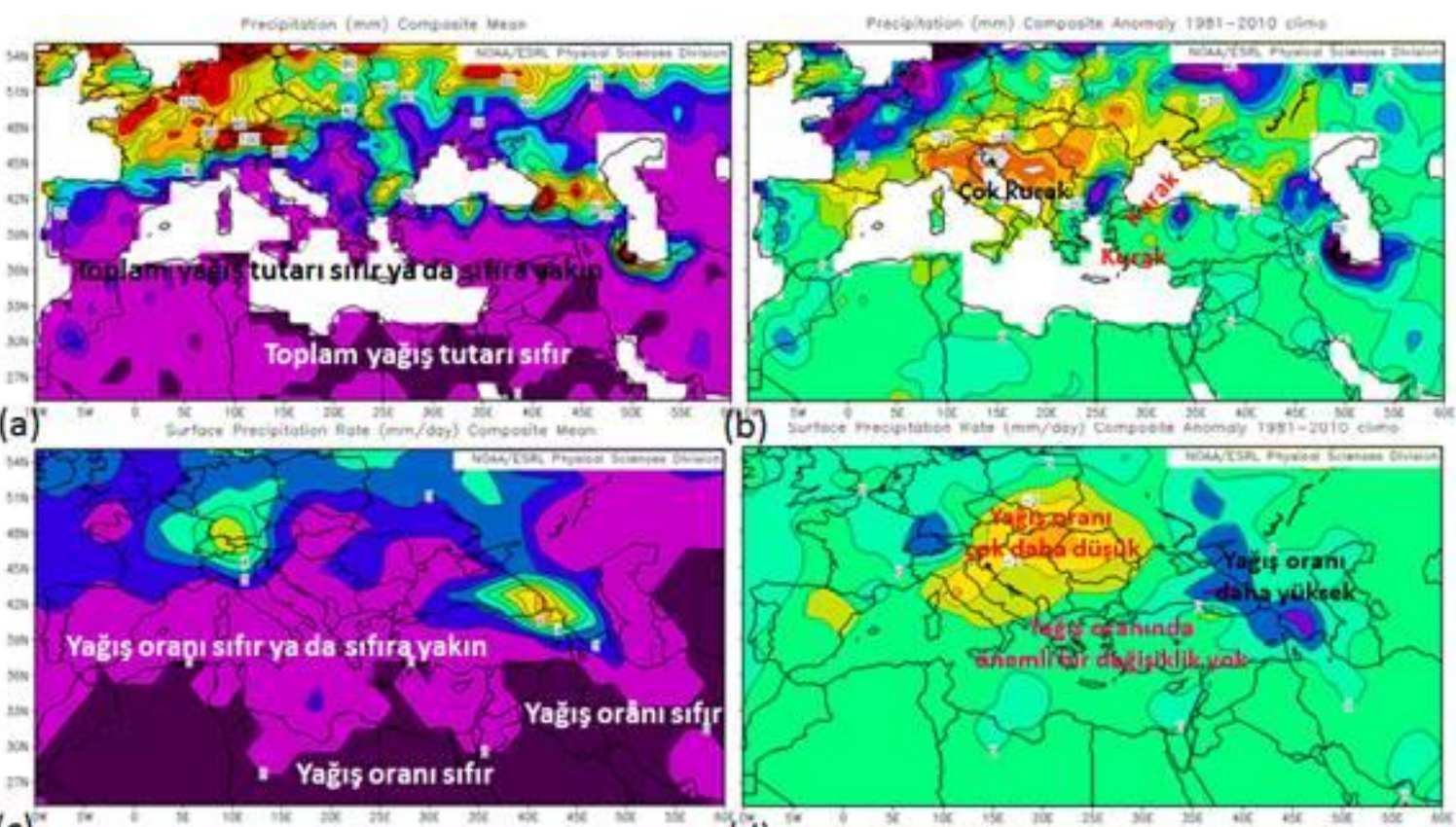

(c)

surfose ois (c) Cumposits then

(d)
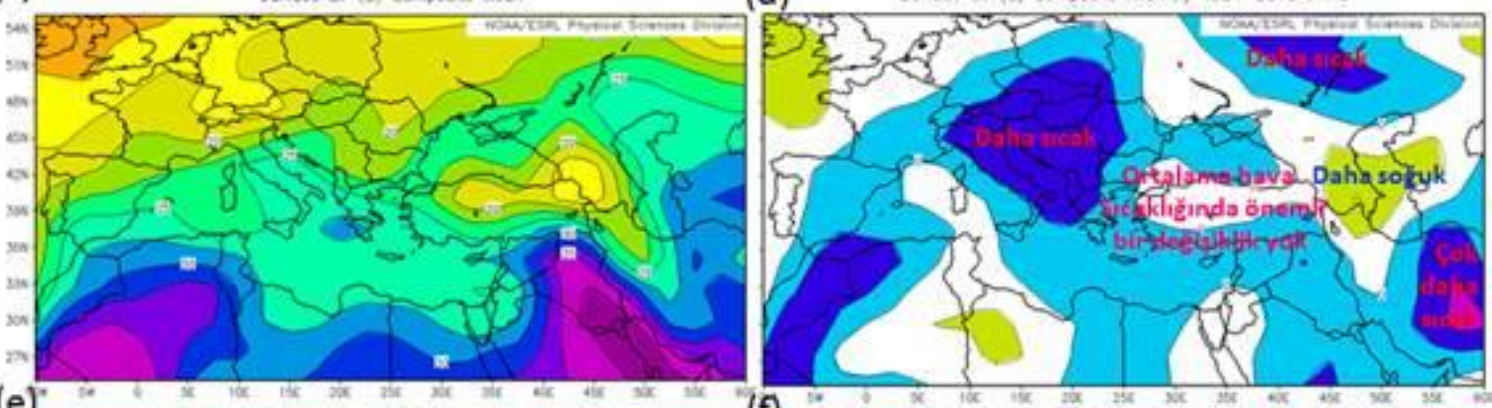

$(\mathrm{e})^{\top}$
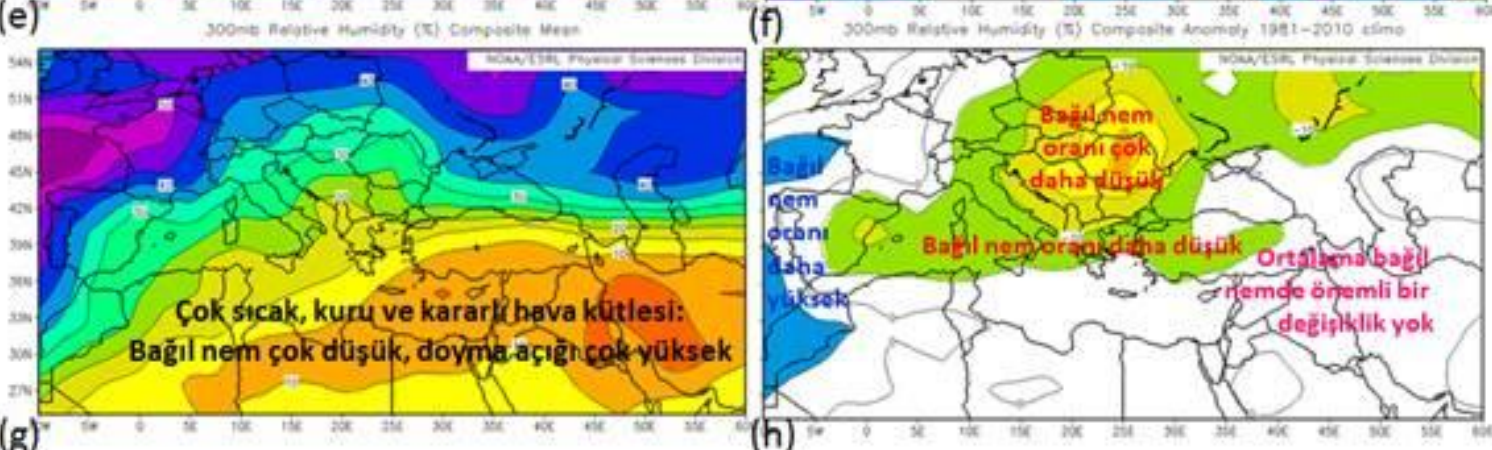

Şekil 11. 2011 yıll Ağustos ayı, (a) birleşik ortalama toplam yağış tutarı (mm) ve (b) anomalisi (mm); (c) birleşik ortalama yüzey yağış oranı ( $\mathrm{mm} /$ gün) ve (d) anomalisi (mm/gün); (e) birleşik ortalama yüzey hava sıcaklığ ${ }^{\circ}\left({ }^{\circ} \mathrm{C}\right)$ ve $(\mathrm{f})$ anomalisi $\left({ }^{\circ} \mathrm{C}\right)$; (g) $1000 \mathrm{hPa}-300 \mathrm{hPa}$ kalınlığında birleşik ortalama atmosferik dikine bağıl nem (\%) ve (h) anomalisinin (\%) geniş Akdeniz Havzası üzerindeki alansal dağılış desenleri.

Ortalama hava sıcaklıkları Türkiye'nin Akdeniz ikliminin egemen olduğu batı ve güney bölgelerinde $25^{\circ} \mathrm{C}$ 'nin üzerindeyken, Güneydoğu Anadolu'da $30^{\circ} \mathrm{C}$ 'ye yaklaşmıştır (Şekil 11e). Akdeniz ikliminin egemenliğindeki bölgelerde biraz daha yüksek olmakla birlikte, ortalama hava sıcaklığ1 uzun süreli ortalamaya göre önemli bir anomali göstermez (Şekil 11f). Bu ayda, Güneş’in görünürdeki mevsimlik hareketi sonucunda 1sınan güney Asya karalar1 üzerinde tropiklerarası yaklaşma kuşağı (ITCZ) ile de birleşerek kısmen dinamik bir özellik kazanan Muson alçak 
Türkeș, M., \& Altan, G. (2014). Türkiye'de 2011'de olușan orman yangınlarının klimatolojik çözümlemesi ve hidroklimatik, yüzey hava ve yüksek atmosfer koşulları ile bağlantilar1. International Journal of Human Sciences, 11(1), 145-176.

basıncının (bkz. Erlat ve Türkeş, 2013; Türkeş, 1998, 2003, 2010; Türkeş ve Erlat, 2003, 2006, vb.) derinleşmesi ve sirkülasyon temelli etki alanını kuzey ve kuzeybatıya doğru genişletmesiyle (bkz. Jones ve ark., 2006; Türkeş ve ark., 2009; Türkeş ve Tatl1, 2011; Tatlı ve Türkeş, 2011, 2013, vb.) bağlantılı olarak, Türkiye'nin güneydoğusu ve Akdeniz kıyı kuşağında tropikal sirkülasyon ve bunun sonucundaysa daha sıcak ve kurak koşullar etkili olmuştur.

Yaz mevsimi genelinde olduğu gibi, ortalama $1000 \mathrm{hPa}-300 \mathrm{hPa}$ atmosfer kalınlığındaki (yaklaşık troposfer, ama kalınlık daha az) bağıl nem dağılışı, Türkiye’nin yazı kurak subtropikal Akdeniz ikliminin egemen olduğu güney yarısında ve batısında, Akdeniz Havzası'nın ve Mezopotamya'nın tümünde çok sıcak, kuru ve kararlı cTWs hava kütlesi egemendir ve doyma açı̆̆1 çok yüksektir (Şekil 11g). Güney Avrupa ve Balkanlar, Türkiye’nin batı ve iç bölgelerinde bağıl nem oranı, uzun süreli ortalamadan daha düşüktür (Şekil 11h).

Ağustos 2011 için buraya kadarki tüm klimatolojik ve meteorolojik açıklama ve karşılaştırmalar, bu ayda Türkiye'nin batı bölgelerinde yangın riskinin ve çıkabilecek orman yangınlarının büyük orman yangınına dönüşme olasıllğının yüksek olduğunu gösterir. Ayrıca, bu noktada, genel olarak kurak ve sıcak geçen 2011 yaz mevsimindeki yüzey toprak, yüzey hava ve yüksek atmosfer koşullarının (sıcak, kurak kararlı, düşük nemlilik ve yüksek doyma açığı, vb.) Eylül ayına devredildiğini ve Eylül'ün bu koşullar altında başladığını vurgulamak gerekir (Şekil 14 ve 15). Türkiye'de 2011 yllında bir gün içerisinde çıkan orman yangını sayısının en çok olduğu 2 Eylül 2011 günü dışında, yangın olayı sayısı ve yanan alanın büyüklüğü açısından öne çıkan başlıca büyük orman yangınlarının çoğunun Ağustos’ta oluşması, bu yüzden beklenen bir sonuçtur.

\subsubsection{8, 23-24 Ağustos ve 1-2 Eylül 2011 günlerinde sinoptik yüzey hava ve yüksek atmosfer koşulları}

Türkiye'de 23 Ağustos 2011 günü çıkan 22 orman yangını, 422.8 ha ile bir gün içerisinde en geniş orman alanının yanmasına ve zarar görmesine neden olmuştur. 23 Ağustos 2011 günü, Türkiye ortalama KBDI değeri 397 ile yangın olasıllğının yüksek ve oldukça yüksek olduğu düzeyler arasındaydı. Öte yandan, Türkiye'de 2011 yılında, bir gün içerisindeki en fazla orman yangını 33 yangın ile 2 Eylül 2011 günü kaydedildi. Aynı gün çıkan 33 orman yangınında 58.8 ha orman alanı zarar görürken, o günün Türkiye ortalaması KBDI değeri 433 ile yangın olasılı̆̆ının oldukça yüksek olduğu düzeye çıkmıştır. Türkiye'de 2011 yılında çıkan orman yangınları içerisinde, 100 hektardan daha fazla yanan alana sahip büyük orman yangını sayısı ise 4'tür. Bunların en büyügü, 18.08.2011 günü Balıkesir OBM’nin Bayramiç Orman İşletme Müdürlügüu’ne bağlı Gökçeiçi Orman İşletme Şefliği ormanlarında çıkan ve 168.5 ha alanın zarar gördüğü orman yangınıdır (Şekil 4b). 
Türkeș, M., \& Altan, G. (2014). Türkiye'de 2011'de olușan orman yangınlarının klimatolojik çözümlemesi ve hidroklimatik, yüzey hava ve yüksek atmosfer koşulları ile bağlantilar1. International Journal of Human Sciences, 11(1), 145-176.
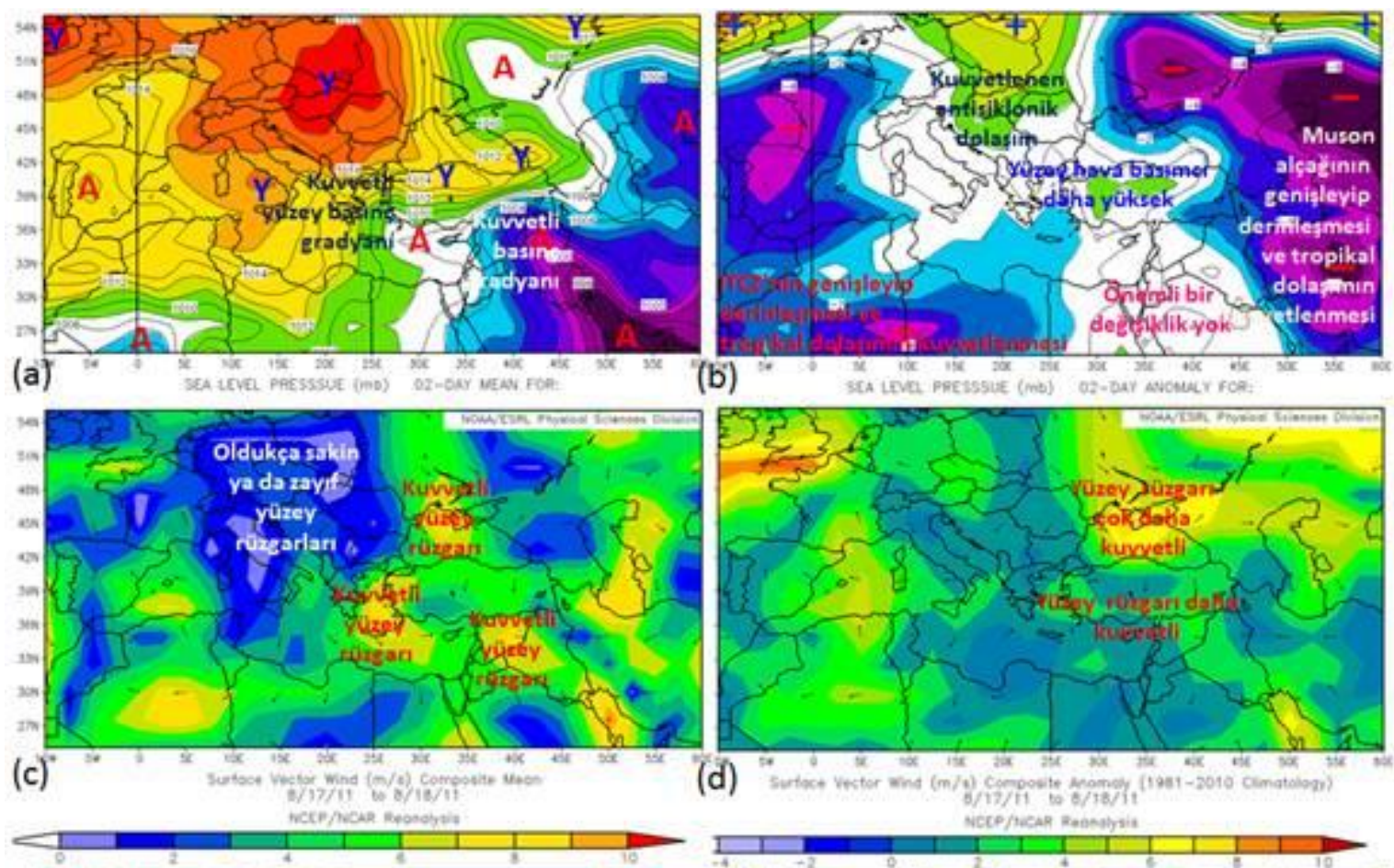

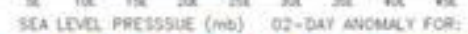

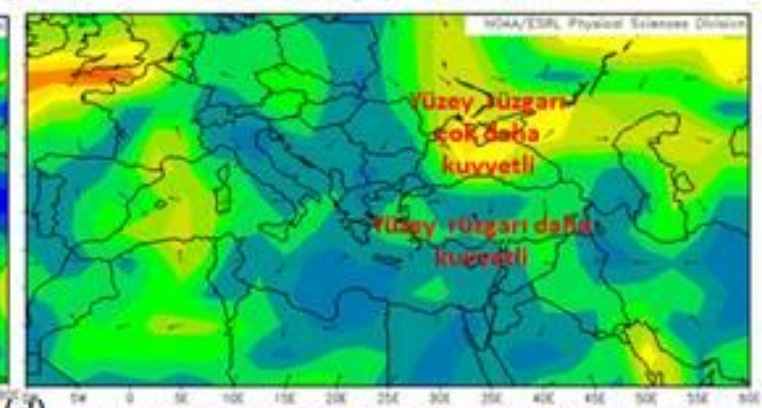

(d)
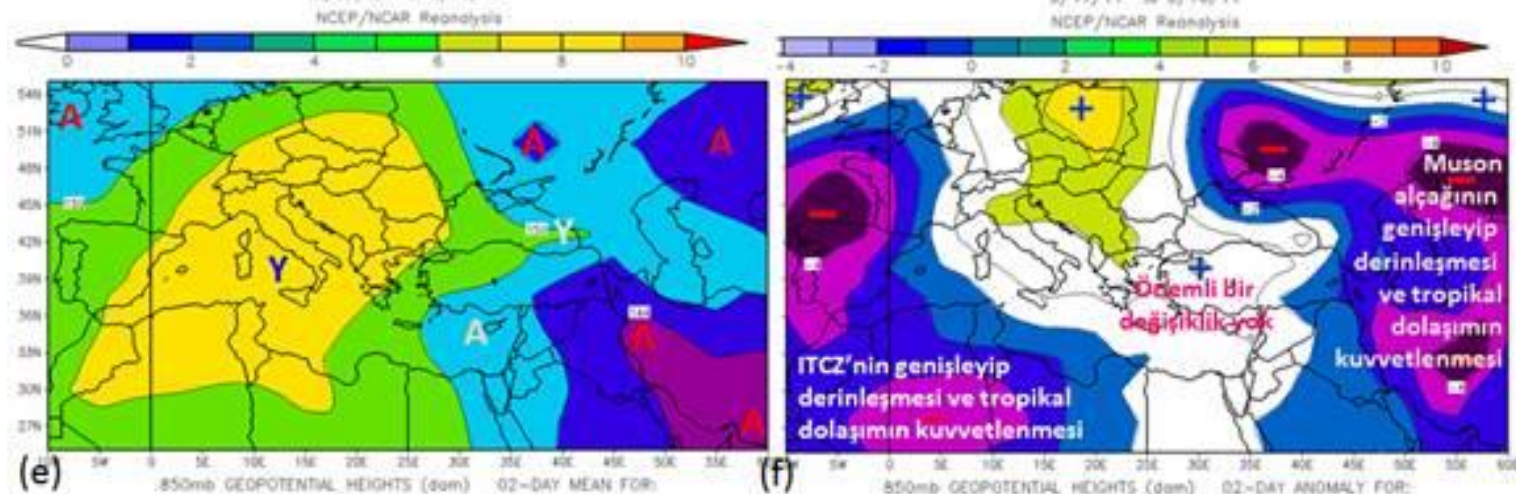

Şekil 12. 17-18 Ağustos 2011 günlerinin, (a) ortalama deniz düzeyi basıncı (hPa) ve (b) anomalisi $(\mathrm{hPa}) ;(\mathrm{c})$ ortalama vektörel yüzey rüzgarı $(\mathrm{m} / \mathrm{s})$ ve $(\mathrm{d})$ anomalisi $(\mathrm{m} / \mathrm{s}) ;(\mathrm{e})$ ortalama $850 \mathrm{hPa}$ jeopotansiyel yükseklik (dam) ve (f) anomalisinin (dam) geniş Akdeniz Havzası üzerindeki alansal dağılış desenleri.

Bu yüzden burada, önce, çıkan 22 orman yangınında 422.8 ha ile bir gün içerisinde en geniş orman alanının yandığı ve zarar gördüğü 23 Ağustos günü etkili olanlara benzer yüzey, yüzey hava ve yüksek atmosfer koşullarına sahip olan 18 Ağustos 2011 Bayramiç orman yangını 17-18 Ağustos günleri dikkate alınarak ayrıntılı olarak incelenecektir (Şekil 12 ve 13). Sonrasındaysa, Eylül’ün hemen başında 33 yangın ile bir gün içerisinde en fazla orman yangınının çıktığı 2 Eylül 2011 yangını, bir gün öncesi de dikkate alınarak çözümlenecektir (Şekil 14 ve 15).

17-18 Ağustos 2011 günlerinde, Türkiye üzerinde, Balkanlar üzerinden Türkiye’ye sokulan sıcak çekirdekli ve derin (dinamik) subtropikal Azorlar yüksek basıncı ile derinleşerek alanını kuzey ve kuzeybatıya doğru genişleten ve kuzey Mezopotamya üzerinden Türkiye ve Doğu Akdeniz’e sokulan sıcak çekirdekli ve sı̆̆ (termik) tropikal muson alçak basıncı arasında kuvvetli bir yüzey basınç gradyanı ve bunun doğal sonucu olarak kuvvetli bir sürtünme katmanı gradyan rüzgarı alanı 
Türkeș, M., \& Altan, G. (2014). Türkiye'de 2011'de olușan orman yangınlarının klimatolojik çözümlemesi ve hidroklimatik, yüzey hava ve yüksek atmosfer koşullanı ile bağlantiları. International Journal of Human Sciences, 11(1), 145-176.

oluşmuştur (Şekil 12ac). Türkiye’nin kuzeybatı, batt-güneybatı ve güneydoğusunu da içeren, Karadeniz, Orta ve Doğu Akdeniz (Levant) havzalarında etkili olan uzun süreli ortalamadan daha kuvvetli ve 1srarlı poyraz ve doğu rüzgarları (gözlem ve vektör rüzgarı ile rüzgar şiri incelenmekle birlikte, burada yalnız vektör rüzgarı verildi) (Şekil 12d), çözümlenen iki günlük ortalama ve anomali deniz düzeyi basıncı desenleriyle açıklanır (Şekil 12ab). Bu basınç ve dolaşım (kısaca hava tipi) deseninde Türkiye çevresindeki kuvvetli yüzey rüzgarı alanlarının ortaya çıkmasında, muson alçağının Türkiye, Karadeniz ve Hazar havzalarına doğru genişleyip derinleşmesinin yanı sıra, Azorlar yüksek basıncının bu mevsimde bat1 Afrika üzerinde etkin olan Batı Afrika musonu tarafindan kuzeye itilerek Doğu Avrupa ve Balkanlara yerleşmesi ve bu bölgelerdeki antisiklonik dolaşımın da kuvvetlenmesini yönlendiren bir başka atmosferik etmen olan ITCZ'nin alanını kuzeye doğru daha fazla genişletmesi, derinleşmesi ve tropikal dolaşımı kuvvetlendirmesidir.

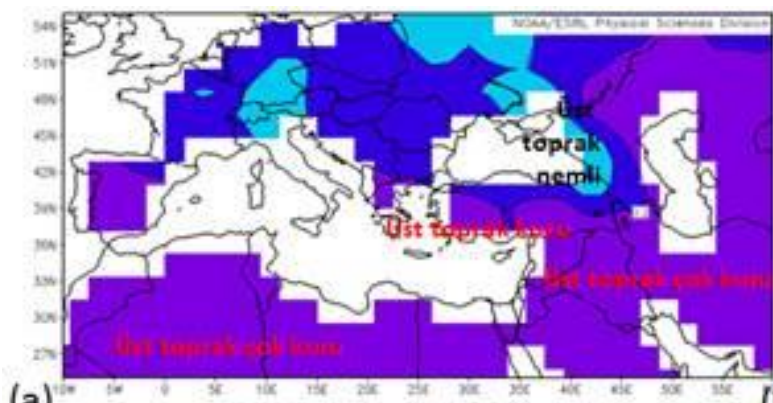

(a)

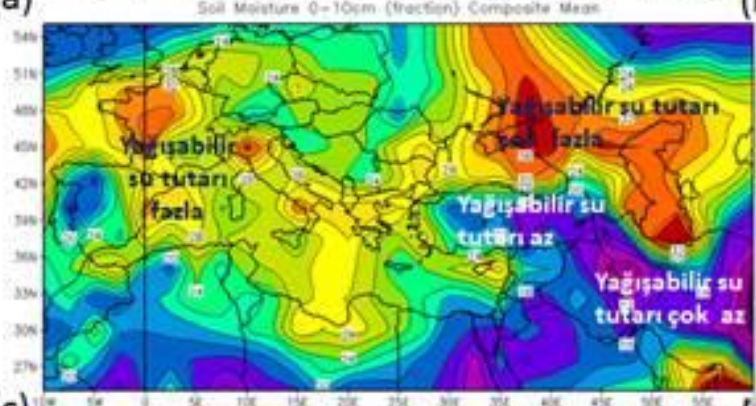

(c)

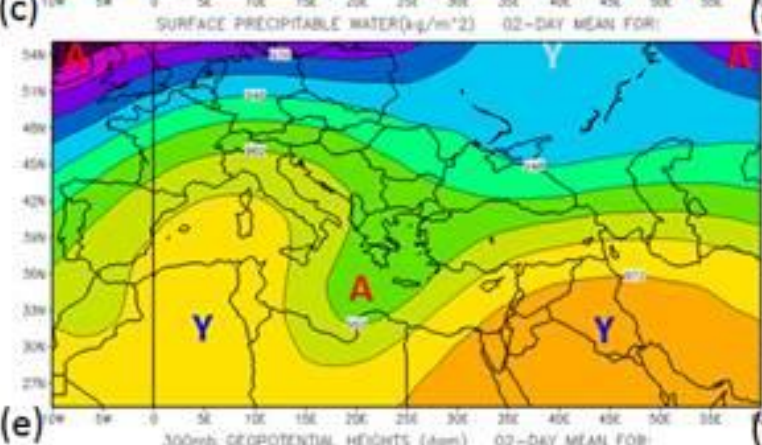

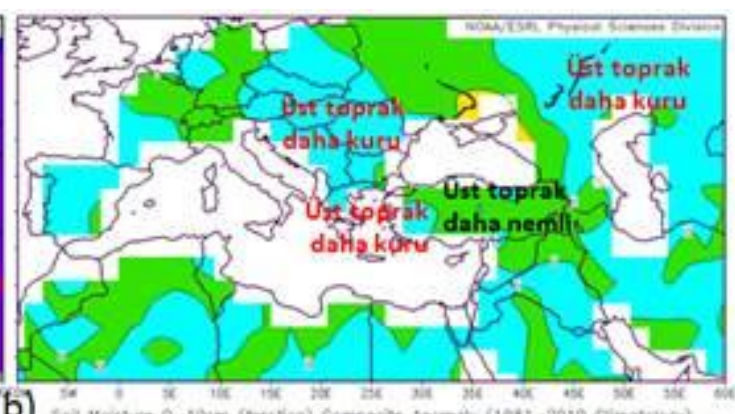

(b)

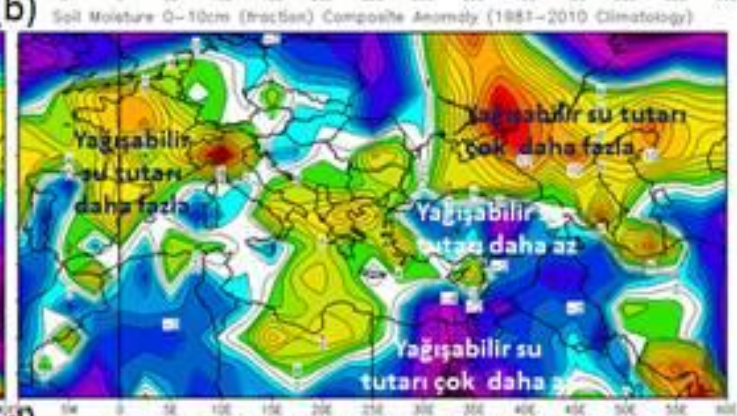

(d)

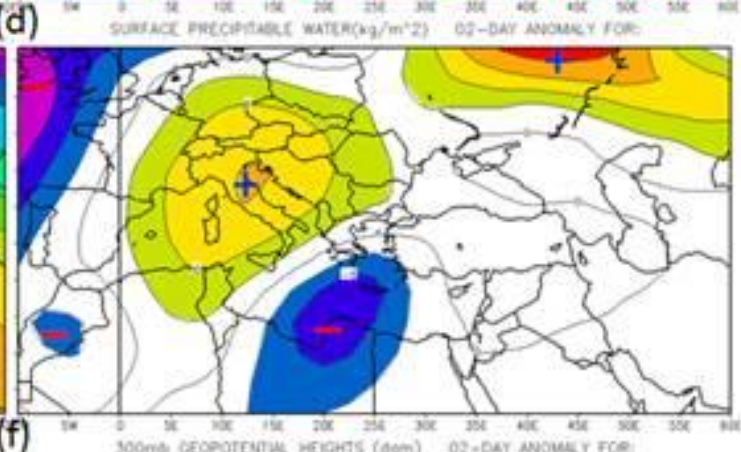

Şekil 13. 17-18 Ağustos 2011 günlerinin, (a) birleşik ortalama 0-10 cm toprak nemi $(* 100=\%$ ) ve (b) anomalisi (* $100=\%$ ); (c) yüzeyde ortalama yağışabilir su tutarı $\left(\mathrm{kg} / \mathrm{m}^{2}\right)$ ve (d) anomalisi $\left(\mathrm{kg} / \mathrm{m}^{2}\right)$; (e) ortalama $300 \mathrm{hPa}$ jeopotansiyel yükseklik (dam) ve (f) anomalisinin (dam) geniş Akdeniz Havzası üzerindeki alansal dağılış desenleri.

Yukarıda açıkladığımız sinoptik hava tipleri, $850 \mathrm{hPa}$ jeopotansiyel yükseklik düzeyi ortalama ve anomali dağılış desenlerinde de görülebilir (Şekil 13ef). Buna göre, Kuzey Afrika'dan 
Türkeş, M., \& Altan, G. (2014). Türkiye'de 2011'de oluşan orman yangınlarının klimatolojik çözümlemesi ve hidroklimatik, yüzey hava ve yüksek atmosfer koşulları ile bağlantiları. International Journal of Human Sciences, 11(1), 145-176.

Batı-Orta Akdeniz ve Orta Avrupa üzerine doğru uzanan yüksek basınç ile muson alçağının 850 $\mathrm{hPa}$ standart basınç düzeyindeki kuzeybatı uzantısını oluşturan termik alçağın ve onun sıcak havasının denetiminde, Orta Avrupa ve Balkanlar üzerindeki antisiklonik anomaliden Hazar Havzası ve İran üzerindeki siklonik anomaliye doğru kuvvetli bir basınç gradyanı ve bu desenin denetiminde de jeostrofik ve termal rüzgarlar oluşmuştur.

18 Ağustos 2011 Bayramiç büyük orman yangını, 17-18 Ağustos günlerinde Akdeniz Havzası'nın hemen her yerinde etkili olan çok düşük ya da sıfır üst toprak nemi ve yağışabilir su tutarlarıyla da açıklanabilir (Şekil 13ab). İki günlük ortalama koşullarda Türkiye’nin Akdeniz iklimiyle nitelenen güney yarısında toprak kuru ve yağışabilir su tutarı çok azdır (Şekil 13ac). Türkiye $300 \mathrm{hPa}$ standart basınç düzeyinde, batıdan konverjans ve sübsidansın, güneydoğu ve doğudan kuvvetli bir yüksek merkezin ve kuzeyden sokulan sıcak havasının etkisi altındadır (Şekil 13e). Bunun sonucuysa, Türkiye'nin batı ve güney bölgeleri üzerinde kararlılık, sübsidans ile alçalan hava kütlesinin adyabatik 1sınması ve bağıl nemin düşmesidir. Uzun süreli ortalama koşullarla karşılaştırıldığındaysa, Türkiye'nin batısında üst toprak daha kuru, karasal iç ve doğu bölgelerdeyse daha nemlidir (Şekil 13b). Kıyı kuşağındaki kuvvetli nemlilik gradyanı dışında, Anadolu'nun çok büyük bölümünde yağışabilir su tutarı normalden çok daha azdır (Şekil 13d). Başka bir deyişle, hem bu günlerde hem de Ağustos genelinde egemen olan hidroklimatolojik ve sinoptik ölçekli atmosfer koşulları (hava tipleri), öteki etmenlerin yanı sıra, olasılıkla 18 Ağustos Bayramiç ve benzer koşullar altında (burada verilmedi) 23 ve 24 Ağustos Seferihisar ve Bergama yangınlarının büyük orman yangınına dönüşmesine neden olmuş olmalıdır.

Görüleceği gibi, 168.5 ha orman alanının zarar gördüğü 18 Ağustos 2011 tarihli Bayramiç orman yangınının büyük orman yangınına dönüşmesi, yangın yönetim ve savaşım etkinliklerindeki olası yanlışlar ve yetersizlikler dışında, yukarıda ayrıntılı olarak açıkladığımız gibi, hem genel olarak 2011 yaz ve Ağustos döneminde hem yangından önceki günü de içeren 17-18 Ağustos 2011 günlerinde bu yörede etkili olan kuvvetli ve 1srarlı kuzeyli (özellikle Etezyen ya da yaz poyrazı) rüzgarlar, düşük hava ve toprak nemliliği ve düşük yağışabilir su tutarı gibi hidroklimatolojik ve atmosferik koşullarla bağlantılı olmalıdır. Hidroklimatolojik ve sinoptik ölçekli hava tipi çözümlemelerine dayanan bu bireşimi ya da önermeyi, yangın indisi değerleri de desteklemiştir. 18.08.2011 tarihli Bayramiç yangın alanının kuzeyindeki Çanakkale Meteoroloji İstasyonunun kuraklık indis değeri 463 ve güneyindeki Balıkesir İstasyonunun kuraklık indisi 539'dur. Bu değerlere göre, yöredeki yangın risk olasıllı̆ı da çok yüksek düzeyindeydi.

Yukarıda değinildiği gibi, 2011 yılının en fazla yanan alana sahip öteki büyük orman yangınlarında, örneğin 23 ve 24 Ağustos 2011 günlerinde, genel olarak 17-18 Ağustos 2011 günlerinde etkili olan kuvvetli ve 1srarlı kuzeyli rüzgarlar (özellikle Etezyen ya da yaz poyrazı), 
Türkeș, M., \& Altan, G. (2014). Türkiye'de 2011'de olușan orman yangınlarının klimatolojik çözümlemesi ve hidroklimatik, yüzey hava ve yüksek atmosfer koşulları ile bağlantilar1. International Journal of Human Sciences, 11(1), 145-176.

düşük hava ve toprak nemliliği ve yağışabilir su tutarı gibi hidroklimatolojik ve sinoptik ölçekli yüzey hava ve yüksek atmosfer koşullarına benzer koşullar altında, İzmir OBM’ye bağlı Seferihisar ve Bergama orman işletme şefliklerinde sırasıyla 352 ha ve 137.4 hektarlık orman alanı yangından zarar görmüştür (Şekil 4a). İzmir’in bu günlere ilişkin KBDI değerleri, sırasıyla 618 ve 623 ’ür. Bu indis değerleri ile yangın olasıllğı her iki günde de kesin yangın olur düzeyine çıkmıştır.
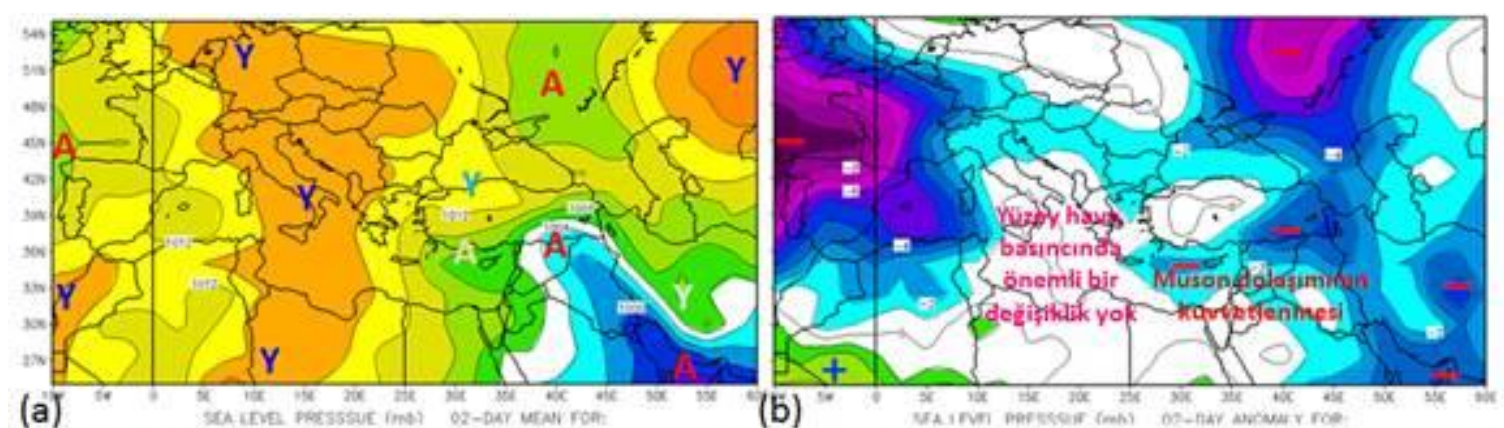

(a)

(b)
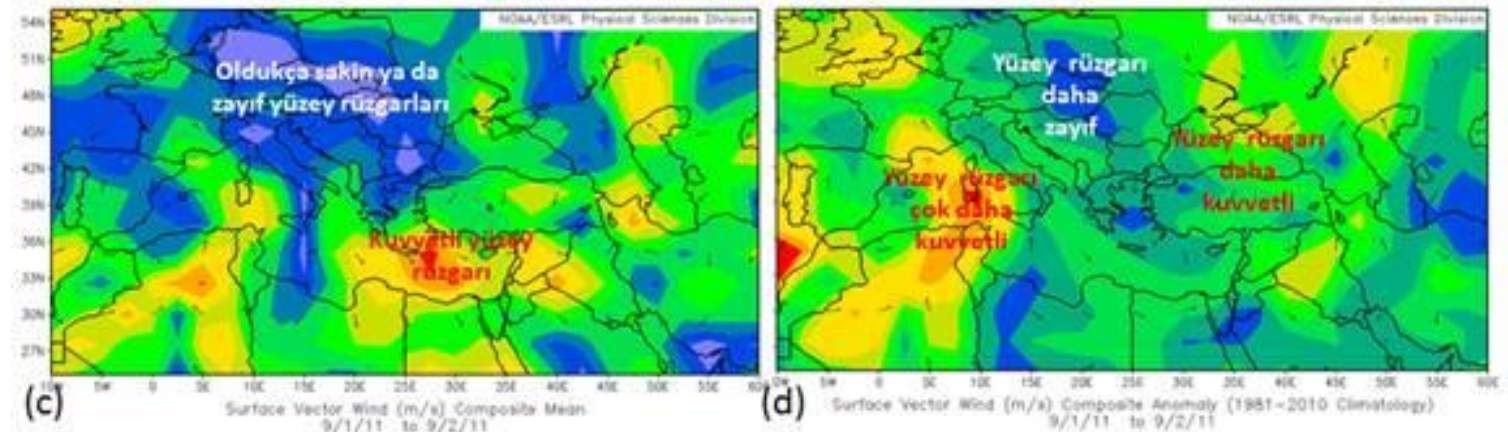

(c)

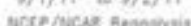

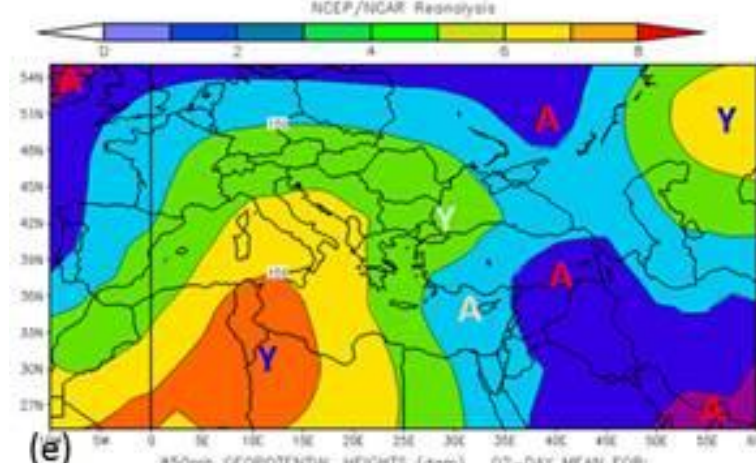

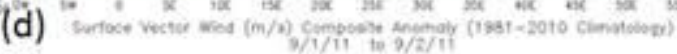

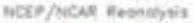

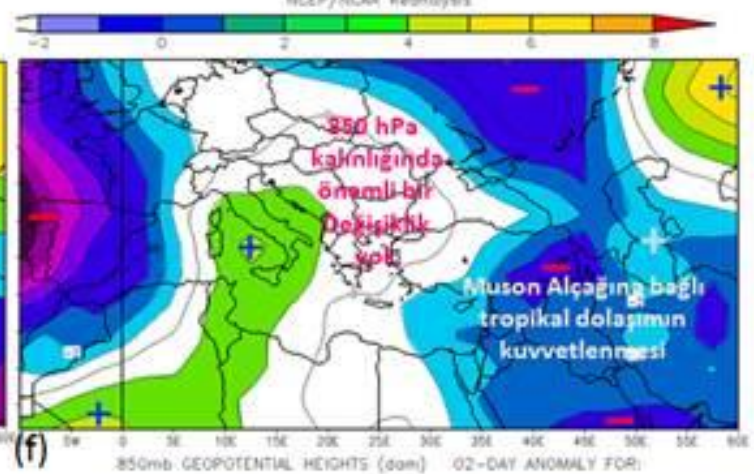

Şekil 14. Çoğunlukla günlük NOAA/ESRL/PSD - NCEP Uygulamalı Veri Seti'ne dayanarak, 1-2 Eylül 2011 günlerinin, (a) ortalama deniz düzeyi basınc1 (hPa) ve (b) anomalisi (hPa); (c) ortalama vektörel yüzey rüzgarı $(\mathrm{m} / \mathrm{s})$ ve (d) anomalisi $(\mathrm{m} / \mathrm{s})$; (e) ortalama $850 \mathrm{hPa}$ jeopotansiyel yükseklik (dam) ve (f) anomalisinin (dam) geniş Akdeniz Havzası üzerindeki alansal dağıllş desenleri.

Son olarak, Eylül'ün hemen başında 33 yangın ile bir gün içerisinde en fazla orman yangınının çıktı̆̆ 2 Eylül 2011 günü için özetle şunlar söylenebilir (Şekil 14 ve 15). Büyük orman yangınlarının oluşmasına ya da gelişmesine çok uygun, buna karşın yangın yönetimi ve savaşım plan ve etkinlikleri açısından çok olumsuz koşulların egemen olduğu sıcak ve kurak bir yaz mevsimi, özellikle Ağustos ayından sonraki düşük toprak ve hava nemliliği düzeyleri ve tropikal muson dolaşımının denetlediği sıcak ve kurak hava koşullarının Eylül'e devredildiği bir zamanda, 2 Eylül 2011'de çıkan orman yangınları, büyük Ağustos yangınlarına benzeyen hidroklimatolojik, yüzey 
Türkeș, M., \& Altan, G. (2014). Türkiye'de 2011'de olușan orman yangınlarının klimatolojik çözümlemesi ve hidroklimatik, yüzey hava ve yüksek atmosfer koşullanı ile bağlantiları. International Journal of Human Sciences, 11(1), 145-176.

hava ve yüksek atmosfer koşullarında (Şekil 14 ve 15) oluşmuş ve bazıları önemli zarar ve kayba neden olmuştur.
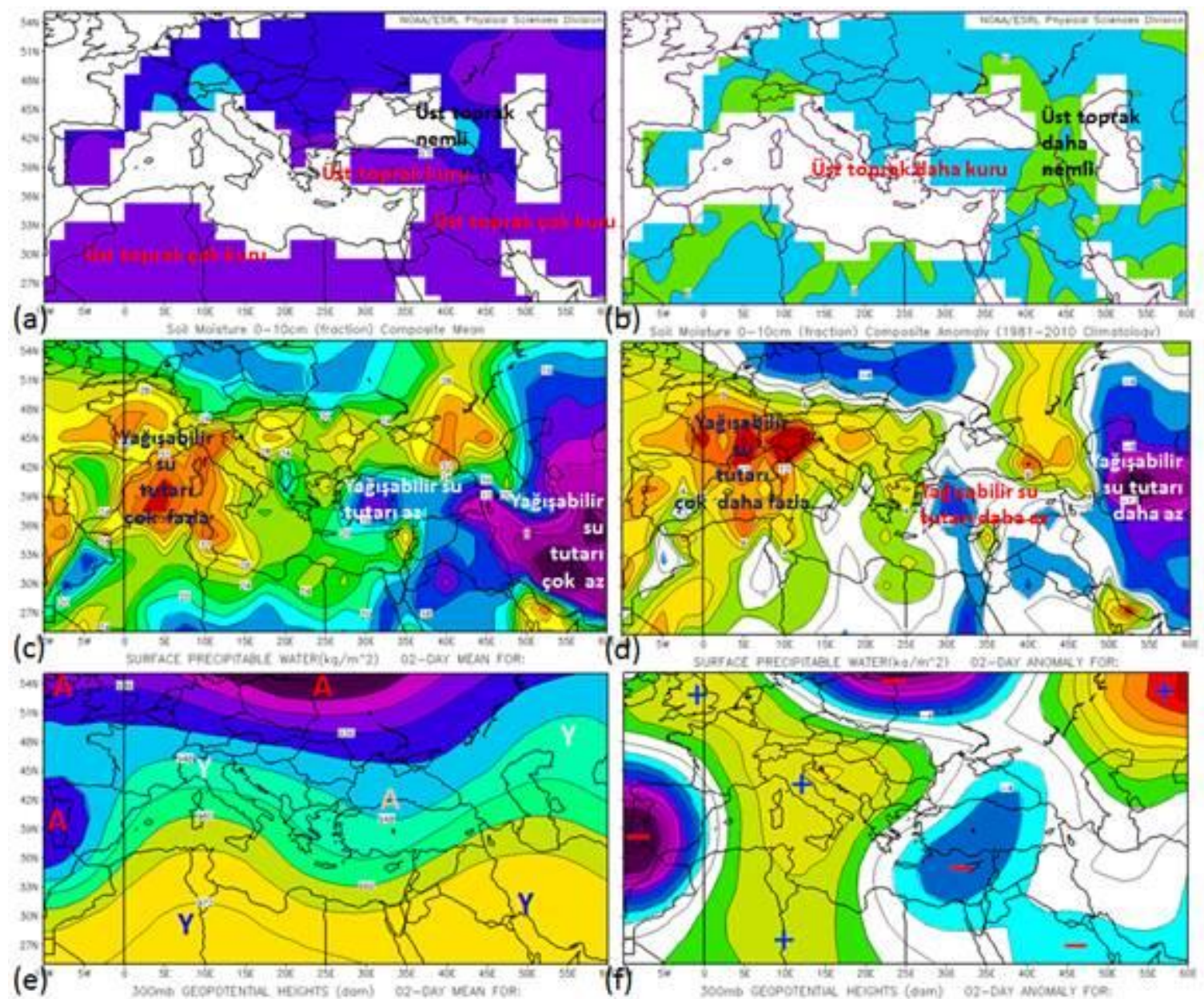

Şekil 15. Çoğunlukla günlük NOAA/ESRL/PSD - NCEP Uygulamalı Veri Seti’ne dayanarak, 1-2 Eylül 2011 günlerinin, (a) birleşik ortalama 0-10 cm toprak nemi $(* 100=\%)$ ve (b) anomalisi $(* 100$ $=\%$; (c) yüzeyde ortalama yağışabilir su tutarı $\left(\mathrm{kg} / \mathrm{m}^{2}\right)$ ve $(\mathrm{d})$ anomalisi $\left(\mathrm{kg} / \mathrm{m}^{2}\right) ;(\mathrm{e})$ ortalama 300 $\mathrm{hPa}$ jeopotansiyel yükseklik (dam) ve (f) anomalisinin (dam) geniş Akdeniz Havzası üzerindeki alansal dağılış desenleri.

Bunlara ek olarak, 2011 yllının 100 hektardan fazla alanı etkileyen 4. büyük orman yangını, 14 Kasım 2011 günü Kahramanmaraş OBM’ye bağlı Samandağ'da çıkan ve 105 hektarlık orman alanının zarar gördüğü yangındır. Bu güne ait kuraklık indis değeri, Antakya meteoroloji istasyonunda 282'dir. Yangın olasılığının orta düzeyde olduğu bu günde ve Kasım ayında kuraklık etkisi şiddetli olmamasına karşın, oluşan yangının bu kadar geniş bir alanı etkileyerek büyük orman yangını sınıfına girmesi, belirleyici faktörün olasılıkla farklı koşullara bağlı olabildiğini gösterir.

\section{Sonuç ve Öneriler}

Türkiye'de 2011 yllında, Keetch-Byram Kuraklık İndisi'ne göre Haziran ayına kadar oldukça düşük düzeylerdeki orman yangını riski, Temmuz ayından başlayarak artış göstererek yangın olasıllğııı da arttırmaya başlamıştır. Ağustos ayıyla birlikte yangın olasıllğı yüksek düzeye 
Türkeş, M., \& Altan, G. (2014). Türkiye'de 2011'de oluşan orman yangınlarının klimatolojik çözümlemesi ve hidroklimatik, yüzey hava ve yüksek atmosfer koşulları ile bağlantilar1. International Journal of Human Sciences, 11(1), 145-176.

ulaşmış, bu dönemdeki yangın sayısı ve yanan alanlar da yılın geride kalan bölümlerine göre daha yüksek olmuştur. Eylül ayı da Ağustos ayında olduğu gibi oldukça yüksek ve kesin yangın olur düzeylerinde yangın olasılı̆̆1 gösterirken, Ekim ayından başlayarak yangın olasıllğı orta ve düşük düzeylere gerilemiştir. Kasım ve Aralık aylarında ise yangın olasılığı düşük ve yok düzeylerine kadar düşmüştür.

2011 yllında, bir gün içerisindeki en fazla orman yangını 33 yangın ile 2 Eylül 2011 günü kaydedildi. Aynı gün çıkan 33 orman yangınında 58.8 ha orman alanı zarar görürken, bu günün Türkiye ortalaması KBDI değeri 433 ile yangın olasılığının oldukça yüksek olduğu düzeye çıkmıştır. Öte yandan, Türkiye'de 23 Ağustos 2011 günü çıkan yangınlar bir gün içerisinde en geniş alanın yanmasına neden olmuştur. 422.8 ha orman alanının zarar gördüğü ve 22 orman yangınının çıktı̆̆1 23 Ağustos 2011 günü, Türkiye ortalama KBDI değeri 397 ile yangın olasılığının yüksek ve oldukça yüksek olduğu düzeyler arasındaydı.

Türkiye'de Aralık ayında bile, 96 orman yangınında yaklaşık 184 ha orman alanının zarar görmüş olması, Türkiye'nin sürdürülebilir orman yönetimi ve orman yangınları ile savaşım ve yangın yönetimi konularında eksiklerinin olduğunu ve kendisini geliştirmesi gerektiğini gösterir. $\mathrm{Bu}$ yüzden, orman yangınları ile savaşım ve yangın risk yönetimi kapsamında, orman işletme alanları ve çeşitli koruma yapılarıyla korunmaya çalışılan özellikle Akdeniz orman ekosistemlerinin, orman yangınlarından etkilenme (bakı) ve etkilenebilirlik (etkiye açık olma) düzeylerinin azaltılması gerekir.

Türkiye'de 2011 yılının son aylarında Orman Genel Müdürlüğü tarafindan yapılan değişikliklerle, orman arazisi Türkiye ortalamasının oldukça üzerinde olan OBM’lerin bazıları başka OBM’ler ile birleştirilerek, uygulamada olumsuz bir durum ortaya çıkmıştır. Buna göre, Sinop OBM Kastamonu OBM ile birleștirilirken, Amasya ve Adana OBM’ler küçültülerek Kayseri OBM oluşturulmuştur. Ayrıca Elazı̆̆ ve Kahramanmaraş OBM’lerin alanları daraltılarak Şanlıurfa OBM kuruldu. Çanakkale OBM'nin güneyde kalan bölümleri Balıkesir OBM’ye, kuzeyde kalan bölümleri ise İstanbul OBM’ye bağlanmıştır.

Çanakkale, Akdeniz iklim bölgesinde olması ve şiddetli yaz kuraklıklarından etkilenmesine karşın, her yıl sayıca çok olmamakla birlikte en az bir büyük orman yangınında geniş orman alanlarını olumsuz etkileyen yangınlarla karşılaşmaktadır. Çanakkale OBM'nin Balıkesir OBM'ye bağlanması ile Çanakkale'de orman yangınlarıyla savaşım daha az kaynak ve daha az personel ile yürütülmeye çalışlacaktır. Bu durum, Akdeniz biyomunun kuzeydeki en üretken, en önemli ve biyolojik çeşitlilik açısından en zengin orman ekosistemi niteliğindeki Çanakkale ormanlarındaki yangınlarla savaşım için son derece olumsuz sonuçlar doğuracaktır. Buna göre yalnız Çanakkale 
Türkeș, M., \& Altan, G. (2014). Türkiye'de 2011'de olușan orman yangınlarının klimatolojik çözümlemesi ve hidroklimatik, yüzey hava ve yüksek atmosfer koşulları ile bağlantilar1. International Journal of Human Sciences, 11(1), 145-176.

için değil, Türkiye’nin Akdeniz iklim bölgesi içerisinde yer alan yüksek yaz hava sıcaklıkları, uzun süreli ve şiddetli yaz kuraklıkları nedeniyle yangın riski en yüksek düzeyde olan OBM’lerin sınırları, görev tanımları, etkilenme ve etkilenebilirlik düzeyleri ve işlevleri belirlenirken de, Akdeniz ikliminin kendine özgü koşulları, yüksek değişkenliği ve yangın klimatolojisi mutlaka dikkate alınmalıdır. Bu kapsamda, bölge müdürlüklerinin sınırları, yukarıda özetlenen özellikleri ve işlevleri belirlenirken ilgili alanlarda çalışmalar yapan bilim adamlarının (orman mühendisi, coğrafyac1, klimatolog, biyocoğrafyacı, biyolog, vb.) düşüncelerine de yer verilmelidir.

Türkiye'de, orman yangınları ile klimatolojik ve meteorolojik (hava, iklim ve iklim değişimleri) koşullar arasındaki ilişkileri, Türkiye’nin çeşitli bölgelerinden örneklerle açıklayan yeterli nitelik ve nicelikteki bilimsel çalışmalar, geç de olsa, son yıllarda yapılmaya başlamıştır. Bu yüzden, bugünkü ve gelecekteki iklim koşullarında orman yangınları ile klimatolojik ve meteorolojik koşul ve olaylar arasındaki ilişkileri Türkiye'nin yangına eğilimli yöre ve bölgelerinden örneklerle açıklamayı hedefleyen çalışmaların yapılması, küresel iklim değişikliğinin olumsuz ve somut etkilerinin görüldüğü ve etkisini arttırdı̆ğ bu yeni dönemde bir zorunluluk haline gelmiştir (örn. Altan ve ark., 2011; Tatlı ve Türkeş, 2013; Türkeş ve Altan, 2012abc; 2013ab; Türkeş ve ark., 2011b, 2012, vb.).

\section{Teşekkür}

Yazarlar, çalışma için seçilen meteoroloji istasyonlarının verilerini sağlayan Meteoroloji Genel Müdürlüğü’ne; 2011 yılı yangın verilerinin kullanılmasını sağlayan Orman Genel Müdürlüğüne; Niğde Üniversitesi Coğrafya Bölümü’nden Dr. Muhammed Z. ÖZTÜRK'e; günlük ve aylık hava ve iklim verileri ile bu verileri hesaplama ve haritalama olanaklarını sağlayan “NOAA/ESRL Physical Sciences Division'a (Daily and monthly weather and climate data and mapping facilities were provided by the NOAA/ESRL Physical Sciences Division, Boulder Colorado from their Web site at http://www.esrl.noaa.gov/psd/psd1/,access: August 2013)" teşekkür etmeyi borç bilmektedir.

\section{Kaynaklar}

Alexander, M. E. (1990). Computer Calculation of the Keetch-Byram Drought Index-Programmers Beware! Fire Management Notes, 51 (4): 23-35.

Altan, G. (2011). Muğla ve Canakkeale İllerinde 2000-2008 Döneminde Gerçeklessen Büyü̈e Orman Yanginlarmm Klimatolojik ve Meteorolojik Analiri, Çanakkale Onsekiz Mart Üniversitesi, Sosyal Bilimler Enstitüsü, Yayımlanmamış Yüksek Lisans Tezi. 364 s.

Altan, G.; Türkeş, M. ve Tatlı, H. (2011). Çanakkale ve Muğla 2009 yllı orman yangınlarının KeetchByram kuraklık indisi ile klimatolojik ve meteorolojik analizi, İçinde: 5. Atmosfer Bilimleri Sempozyumu Bildiriler Kitabı, s.263-274, 27-29 Nisan 2011: İstanbul.

Altınsoy, H., Öztürk, T., Türkeş, M. and Kurnaz, M. L. (2011). Projections of future air temperature and precipitation changes in the Mediterranean Basin by using the global climate 
Türkeş, M., \& Altan, G. (2014). Türkiye'de 2011'de oluşan orman yangınlarının klimatolojik çözümlemesi ve hidroklimatik, yüzey hava ve yüksek atmosfer koşulları ile bağlantiları. International Journal of Human Sciences, 11(1), 145-176.

model. In: Proceedings of the National Geographical Congress with International Participation (CD-R), ISBN 978-975-6686-04-1, s.7-10 September 2011: İstanbul, (in Turkish with an English abstract).

Altınsoy, H., Öztürk, T., Türkeş, M. and Kurnaz M. L. (2012). Simulating the climatology of extreme events for the central Asia domain using the RegCM 4.0 regional climate model. In: Advances in Meteorology, Climatology and Atmospheric Physics (C.G. Helmis and P. Nastos, eds.), pp.365-370. Springer Atmospheric Sciences, Springer-Verlag, Berlin.

Anonim, (2013a). http://climate.geog.udel.edu/ climate/html.pages/README.ghcnclim.html; www.esrl.noaa.gov/psd/psd1/.Erişim tarihi: 20.08.2013.

Anonim, (2013b). http://sslmaps.tamu.edu/website/kbdi/viewer.htm. Erişim tarihi: 01.09.2013.

Anonim, (2013c). http:// flame.fl-dof.com/fire_weather/KBDI/. Erişim tarihi: 01.09.2013.

Anonim, (2013d). www.sentezhaber.com/izmirde-orman-yangini-h51330.html. Erişim tarihi: 21.07.2013.

Anonim, (2013e). www.sabah.com.tr/multimedya/galeri/turkiye/bayramicte-orman-yangini-koyesicradi?albumId $=35978 \& \mathrm{tc}=9$ \&page $=3$. Erişim tarihi: 21.07.2013.

Carvalho, A.; Flannigan, M. D.; Logan, K.; Miranda, A. I. and Borrego, C. (2008). Fire activity in Portugal and its relationship to weather and the Canadian FireWeather Index System. International Journal of Wildland Fire, 17: 328-338.

Carvalho, A. C.; Carvalho, A.; Martins, H.; Marques, C.; Rocha, A.; Borrego, C.; Viegas, D. X. and Miranda, A. I. (2011). Fire weather risk assessment under climate change using a dynamical downscaling approach. Environmental Modelling \& Software, 26: 1123-1133.

Dolling, K.; Chu, P-S. and Fujioka, F. (2005). A climatological study of the Keetch - Byram Drought Index and fire activity in the Hawaiian Island. Agricultural and Forest Meteorology, 133: 17-27.

Erlat, E. and Türkeş, M. (2013). Observed changes and trends in numbers of summer and tropical days, and the 2010 hot summer in Turkey. International Journal of Climatology, 33(8): 1898-1908.

Flannigan, M. D.; Stocks, B. J. and Wotton, B. M. (2000). Climate change and forest fires. The Science of the Total Environment, 262: 221 - 229.

Goodrick, S. L. (2003). Incorporation of radar precipitation estimates in a Drought Index applicable to wildland fire. In: Proceedings of the 2003 Georgia Water Resources Conference. April 2324 Athens.

Heim, R. R. (2002). A Review of Twentieth-Century Drought Indices Used in the United States. American Meteorological Society, 83: 1149-1165.

Janis, M. J.; Johnson, M. B. and Forthun, G. (2002). Near-real time mapping of Keetch-Byram drought index in the south-eastern United States. International Journal of Wildland Fire, 11: 281289.

Jones, M. D., Roberts, C. N., Leng, M. J. and Türkeş, M. (2006). A high-resolution late Holocene lake isotope record from Turkey and links to North Atlantic and monsoon climate. Geology, 34: 361-364.

Kalnay, E., and Coauthors, (1996). The NCEP/NCAR 40-Year Reanalysis Project. Bulletin of the American Meteorological Society, 77: 437-471. doi: http://dx.doi.org/10.1175/15200477(1996)077<0437: TNYRP>2.0.CO;2. Erişim tarihi: 01.09.2013.

Keetch, J. J. and Byram, G. M. (1968). A drought index for forest fire control. USDA Forest Service Research Paper, SE-38: 1-32.

Kuglitsch, F. G.; Toreti, A.; Xoplaki, E.; Della-Marta, P. M.; Zerefos, C. S.; Türkeş, M. and Luterbachers, J. (2010). Heat wave changes in the eastern Mediterranean since 1960, Geophysical Research Letters, 37, L04802, doi:10.1029/2009 GL041841.

Moriondo, M.; Good, P.; Durao, R.; Bindi, M.; Giannakopoulos, C. and Corte-Real, J. (2006). Potential impact of climate change on fire risk in the Mediterranean area. Climate Research, 31, $85-95$.

OGM, (2012). TC Orman ve Su İşleri Bakanlığ1, Orman Genel Müdürlüğü, Yangın Harekat Merkezi, 2011 Yul Orman Yangznlarn ile Mücadele Faaliyetleri Değerlendirme Raporu. 97 sayfa. 
Türkeş, M., \& Altan, G. (2014). Türkiye'de 2011'de oluşan orman yangınlarının klimatolojik çözümlemesi ve hidroklimatik, yüzey hava ve yüksek atmosfer koşulları ile bağlantıları. International Journal of Human Sciences, 11(1), 145-176.

Öztürk, T., Altınsoy, H., Türkeş, M. and Kurnaz M. L. (2011). Simulation of extreme events for the Central Asia cordex domain by using the RegCM 4.0. In: 5th Atmospheric Science Symposium Proceedings Book, pp.475-484. Istanbul Technical University, 27-29 April 2011: İstanbul.

Öztürk, T.; Altınsoy, H.; Türkeş, M. and Kurnaz, M. L. (2012). Simulation of temperature and precipitation climatology for the Central Asia CORDEX domain using RegCM 4.0, Climate Research, 52: 63-76.

Öztürk, T., Türkeş, M. and Kurnaz, M. L. (2013). Projected changes in air temperature and precipitation climatology in Turkey by using RegCM 4.3. In: Proceedings of European Geosciences Union General Assembly 2013, 07 - 12 April 2013, Vienna.

Sen, B.; Topçu, S.; Türkeş, M.; Şen, B. and Warner, J. F. (2012). Projecting climate change, drought conditions and crop productivity in Turkey. Climate Research, 52: 175-191.

Tatli, H. and Türkeş, M. (2011). Empirical orthogonal function analysis of the Palmer drought indices. Agricultural and Forest Meteorology, 151 (7): 981-991.

Tatl, H. and Türkeş, M. (2013). Climatological evaluation of Haines forest fire weather index over the Mediterranean basin. Meteorological Applications. DOI: 10.1002/met.136 (In press).

Türkeş, M. (1996). Spatial and temporal analysis of annual rainfall variations in Turkey, International Journal of Climatology, 16: 1057-1076.

Türkeş, M. (1998). Influence of geopotential heights, cyclone frequency and Southern Oscillation on rainfall variations in Turkey. International Journal of Climatology, 18: 649-680.

Türkeş, M. (1999). Vulnerability of Turkey to desertification with respect to precipitation and aridity conditions. Turkish Journal of Engineering and Environmental Science, 23: 363-380.

Türkeş, M. (2003). Spatial and temporal variations in precipitation and aridity index series of Turkey. In: Mediterranean Climate - Variability and Trends (Bolle, H.J., ed.), Regional Climate Studies. Springer Verlag: Heidelberg: 181-213.

Türkeş, M. (2007). Türkiye’nin kuraklığa, çölleşmeye eğilimi ve iklim değişikliği açısından değerlendirilmesi. Pankobirlik, 91: 38-47.

Türkeş, M. (2008a). Gözlenen iklim değişiklikleri ve kuraklık: Nedenleri ve geleceği. Toplum ve Hekim, 23: 97-107.

Türkeş, M. (2008b). Küresel iklim değişikliği nedir? Temel kavramlar, nedenleri, gözlenen ve öngörülen değişiklikler. İklim Deģ̆̈sikliği ve Çevre, 1: 45-64.

Türkeş, M. (2010). Klimatoloji ve Meteoroloji. Birinci Bask1, Kriter Yayınevi - Yayın No. 63, Fiziki Coğrafya Serisi No. 1, ISBN: 978-605-5863-39-6, 650 + XXII sayfa: İstanbul.

Türkeş, M. (2011). Dünyada ve Türkiye'de iklim değişikliği, kuraklık ve çölleşme. In: II. Ulusal Toprak ve Su Kaynaklar Kongresi Bildiri Kitabı (EK), s.5-19. Ankara Toprak Gübre ve Su Kaynakları Merkez Araştırma Enstitüsü Müdürlüğü, 22-25 Kasım 2011: Kızılcahamam.

Türkeş, M. (2012a). Küresel İklim Değişikliği ve Çölleşme. İçinde: Günümür Dünya Sorunlar Disiplinlerarası Bir Yaklaşım (ed. N. Özgen), s.1-42. Eğiten Kitap: Ankara.

Türkeş, M. (2012b). Kuraklık, Çölleşme ve Birleşmiş Milletler Çölleşme ile Savaşım Sözleşmesi’nin Ayrıntılı bir Çözümlemesi. Marmara Avrupa Arastırmalar Dergisi, 20 (1): 7-55.

Türkeş, M. (2013). Türkiye'de gözlenen ve öngörülen iklim değişsikliği, kuraklık ve çölleşme. Ankara Üniversitesi Cevre Bilimleri Dergisi. (Gözden geçirmede).

Türkeş, M. ve Altan, G. (2011). Çanakkale Yöresi’nde gözlenen kurak ve nemli koşulların iklim değişimleri açısından çözümlenmesi. İçinde: X. Ekoloji ve Çevre Kongresi Bildiri Özretleri Kitabı, s.55, 04-07 Ekim 2011: Çanakkale.

Türkeş, M. ve Altan, G. (2012a). Kaz Dağı Yöresi’nde orman yangınlarının kuraklık indisi ile analizi ve iklim değişimleriyle ilişkisi. İçinde: Kazdağlar 3. Ulusal Semposyumu Bildiriler Kitabı, s.83-94, 24-26 Mayıs 2012: Edremit-Güre.

Türkeş, M. ve Altan, G. (2012b). Muğla Orman Bölge Müdürlügü’ne bağlı orman arazilerinde 2008 yılında çıkan yangınların kuraklık indisleri ile çözümlenmesi. Uluslararası İnsan Bilimleri Dergisi, 9(1): 912-931.

Türkeş, M. ve Altan, G. (2012c). Çanakkale'nin 2008 yılı büyük orman yangınlarının meteorolojik ve hidroklimatolojik analizi. Coğrafi Bilimler Dergisi, 10 (2): 195-218. 
Türkeş, M., \& Altan, G. (2014). Türkiye'de 2011'de oluşan orman yangınlarının klimatolojik çözümlemesi ve hidroklimatik, yüzey hava ve yüksek atmosfer koşulları ile bağlantilar1. International Journal of Human Sciences, 11(1), 145-176.

Türkeş, M. ve Altan, G. (2013a). Muğla Yöresi’nde gözlenen kuraklıkların ve nemli koşulların doğal çevreye etkileri ve iklim değişikliği açısından analizi. İçinde: The 3rd International Geography Symposium GeoMed2013 Proceedings Book, June 10-13: Antalya.

Türkeş, M. ve Altan, G. (2013b). Muğla yöresi ormanlarının yangın klimatolojisi. İçinde: Türkiye Coğrafyacular Derneği Yillke Kongresi (TCDYK) 2013 Bildiriler Kitabı, s.460-467, 19-21 Haziran 2013, İstanbul.

Türkeş, M. and Erlat, E. (2003). Precipitation changes and variability in Turkey linked to the North Atlantic Oscillation during the period 1930-2000. International Journal of Climatology, 23: 1771-1796.

Türkeş, M. and Erlat, E. (2006). Influences of the North Atlantic Oscillation on precipitation variability and changes in Turkey. Nuovo Cimento Della Societa Italiana Di Fisica C-Geophysics and Space Physics, 29: 117-135.

Türkeş, M. and Sümer, U. M. (2004). Spatial and temporal patterns of trends and variability in diurnal temperature ranges of Turkey. Theoretical and Applied Climatology, 77: 195-227.

Türkeş, M. and Tatl, H. (2011). Use of the spectral clustering to determine coherent precipitation regions in Turkey for the period 1929-2007. International Journal of Climatology, 31: 20552067.

Türkeş, M., Sümer, U. M. and Demir, İ. (2002). Re-evaluation of trends and changes in mean, maximum and minimum temperatures of Turkey for the period 1929-1999. International Journal of Climatology, 22: 947-977.

Türkeş, M., Sümer, U. M. ve Yıldırım, Y. E. (2005). GAP Bölgesi’nde gözlenen uzun süreli iklimsel değişimlerin ve eğilimlerin zaman dizisi çözümlemeleri. İçinde: Ulusal Coğrafya Kongresi 2005 (Prof. Dr. İsmail Yalçnlar Anısma) Bildiriler Kitabr. 373-384. İstanbul Üniversitesi Edebiyat Fakültesi, İstanbul.

Türkeş, M., Koç, T. and Sarış, F. (2009). Spatiotemporal variability of precipitation total series over Turkey. International Journal of Climatology, 29: 1056-1074.

Türkeş, M.; Altan, G. ve Öztürk, M. Z. (2012). Türkiye'de 2011 yılı orman yangınlarının KeetchByram kuraklık indisi ile analizi. İçinde: Ankara Üniversitesi TÜCAUM VII. Coğrafya Kongresi 2012 Bildiriler Kitabı, s.30-35. 18-19 Ekim 2012, Ankara.

Türkeş, M., Kurnaz, M. L., Öztürk, T. and Altınsoy, H. (2011a). Climate changes versus 'security and peace' in the Mediterranean macroclimate region: are they correlated? In: Proceedings of International Human Security Conference on Human Security: New Challenges, New Perspectives, pp.625-639, 27-28 October 2011: İstanbul.

Türkeş, M.; Tatl, H.; Altan, G. ve Öztürk, M. Z. (2011b). Çanakkale ve Muğla 2010 yllı orman yangınlarının Keetch-Byram kuraklık indisi ile analizi. İçinde: Uluslararası Katılımlı Coğrafja Kongresi 2011 Bildiriler Kitabr, s.589-602, 07-10 Eylül 2011: İstanbul.

Xanthopoulos, G.; Maheras, G.; Gouma, V. and Gouvas, M. (2006). Is the Keetch-Byram drought index (KBDI) directly related to plant water stress? In: $V$. International Conference on Forest Fire Research, 27-30 November 2006, Coimbra.

Yamak, Ç. (2006). Investigation over a national meteorological fire danger approach for Turkey with geographic information systems. A Thesis Submitted to the Graduate School of Natural and Applied Sciences of Middle East Techinical University in Partial Fulfillment of the Requirements for the Degree of Master of Science in Geodetic and Geographic Information Technologies. 142 p.

Yıldırım, Y. E., Türkeş, M. and Tekiner, M. (2004). Time-series analysis of long-term variations in stream-flow data of some stream-flow stations over the Gediz Basin and in precipitation of the Akhisar Station. Pakistan Journal of Biological Sciences, 7: 17-24. 
Türkeş, M., \& Altan, G. (2014). Türkiye'de 2011'de oluşan orman yangınlarının klimatolojik çözümlemesi ve hidroklimatik, yüzey hava ve yüksek atmosfer koşulları ile bağlantiları. International Journal of Human Sciences, 11(1), 145-176.

\section{Extended English Abstract}

In the year of 2011, wildfires became one of the most important disasters for the Turkish forests, which are considered within the Mediterranean macro-climate belt and biome. KBDI calculated for the year of 2011 reached the highest values in August and September, and spatially in the west and southern regions of the Anatolian Peninsula mainly characterised with the Mediterranean climate and rainfall regime. The regions characterised with the highest level of fire probability consisted of the Regional Forest Administrations of Balıkesir, Izmir and Denizli at the west, and Isparta and Mersin at the south. The summer of 2011 that was hotter and drier (less humid and less rainy) than the normal at the Eastern Mediterranean, northern Mesopotamia, west and south regions of Turkey, August had the largest burned area, whereas September was characterised with maximum number of the forest fires. According to the fire determination ratios, $40 \%$ of fire frequency and 36\% of burned areas are closely linked to fire-prone hydroclimatic and synoptic-scale weather conditions with a considerable high probability level of fire event.

A forest fire is defined as a set of fires, which tend to spread freely in the forests and to destroy all living organisms or death organic materials and residuals under the forest area that are combustible. A combination of three factors consisting of flammable material, heat and oxygen is defined as the burning event. One of these three factors should be eliminated to end the fire. In many countries and also in Turkey, forest fires are the main factors threatening the forest ecosytems and services. Forest fires have great negative impacts on forested areas over the various floristic regions or the biomes of the world each year reaching the billions of dollars to spend for fire-fighting, life, property and loss of recreational value. The potential of the forest fires is directly related to the climate and weather conditions of the regions and somewhat with the human activities and settlements. Specific climate and weather conditions cause burning effects and tendencies of forest by changing physical and chemical properties of flammable materials. In order to have the effective fire-fighting or mitigating techniques, there should be the complete information of weather forecast and flammable substances. When the meteorological information and estimates required in the event of a fire are not known or inadequate, then it is impossible to know how fire will behave and/or to know effectiveness of the method of choice in the fire fight. For the large part of Turkey, especially in the western and southern regions, the summers are mostly hot and dry, while winters are characterized with mostly mild and rainy Mediterranean climate facing significant forest fires every year (Türkeş, 1999, 2007, 2010, 2012b; Türkeş et al., 2012), and an about $90 \%$ of forest fires in Turkey are of the human origin (Altan $e t$ al., 2011).

The signs of increases in forest fires have already been experienced in many parts of subtropical and tropical climate zones, countries neighbouring the Mediterranean Basin from the north and west and Turkey (Tatli and Türkeş, 2013; Türkeş and Altan, 2011, 2012bc; etc.). As a result of the direct influence of the Mediterranean climate, a large area over Turkey is dominated by hot and dry summers except the Black Sea region and the North-East Anatolia sub-region (Türkeş, 1998, 1999, 2007, 2010). According to the observed climate change and variability studies, there have been evident decreases in precipitation amounts particularly in winter season over the Mediterranean climate regions of Turkey since the early 1970s (e.g. Türkeş, 1998, 1999, 2011, 2012a, 2013; Türkeş and Tatli, 2011; Türkeş et al., 2009), and significant increases in spring and summer average mean air temperatures and particularly in spring, summer and yearly average minimum air temperatures in most of Turkey (e.g. Kuglitsch et al., 2010; Türkeş, 2011, 2012b; Türkeş et al., 2002; Türkeş and Sümer, 2004, etc). Due to the evident influences of the drought events and long-lasting extreme higher maximum and minimum air temperature conditions (i.e. heat waves), requirements for the surface and ground-water resources were increased and significant decreases in the water resources were recorded in many geographical districts and subregions of Turkey, particularly in the Aegean, Marmara, continental Central and South-eastern 
Türkeş, M., \& Altan, G. (2014). Türkiye'de 2011'de oluşan orman yangınlarının klimatolojik çözümlemesi ve hidroklimatik, yüzey hava ve yüksek atmosfer koşulları ile bağlantiları. International Journal of Human Sciences, 11(1), 145-176.

Anatolia regions (Türkeş and Altan, 2011, 2013ab; Altan et al., 2011; Türkeş, 1996, 1998, 1999, 2003, 2012ab; Türkeş et al., 2005, 2009; Yıldırım et al., 2004). Many and larger area forest fires occurred in the summers of 2007 and 2008 are a good example for the influences of the severe drought conditions in Turkey (Türkeş and Altan, 2011, 2012bc).

In addition to the increased summer dryness and drought events, heat waves are of among the forest fire leading factors in the Mediterranean countries including Turkey (Carvalho et al., 2008; Erlat and Türkeş, 2013; Kuglitsch et al., 2010; Tatlı and Türkeş, 2013; Türkeş, 2007, 2010, 2012ab; vb.). Furthermore, significant increases in the frequencies, intensity and magnitudes of the forest fires have been projected under the much warmer, drier, higher year-to-year variability, and more vulnerable to extreme weather and climate events and disasters in the Mediterranean Basin (e.g. Altınsoy et al., 2011, 2012; Carvalho et al., 2011; Flannigan et al., 2000; Sen et al., 2012; Ozturk et al., 2011, 2012, 2013; Türkeş, 2011, 2012b; Türkeş et al., 2011 ab; etc.).

Purpose of the study is to analyse spatial and temporal distribution patterns and causes of forest fires in Turkey occurred in the year of 2011, based on the Keetch-Byram Drought Index (KBDI) calculated by using data of 75 climatology/meteorology stations and to determine the relationship between hydroclimatic, synoptic-scale surface weather and upper atmosphere conditions, and occurrence time and magnitude of the forest fires.

\section{Data and Method}

This study has used the Keetch-Byram Drought Index in order to determine the fire-prone risky days, to determine or forecast, to intervene and mitigate the forest fires, which have been used by the forest management and conservation services in many countries including the United States (U.S.). This index was firstly developed by Keetch and Byram in 1968 for the U.S. Forest Service under the Ministry of Agriculture based on soil moisture and other parameters to predict the likelihood of meteorological drought. The most important feature of the index is to establish a link between drought conditions and forest fires by using the soil moisture content, maximum air temperature and precipitation data in order to determine the days of having a risk for forest fires (Keetch and Byram, 1968). Depending on the weather is rainy or virtually rainless; KBDI value is calculated by considering many specific criterions for making an objective decision (Keetch and Byram, 1968; Alexander, 1990; Heim, 2002; Goodrick, 2003; Dolling et al, 2005; Yamak, 2006; Altan, 2011; Altan et al., 2011; Türkeş et al., 2011a; Türkeş and Altan, 2012abc).

In order to investigate the hydro-climatological and synoptic climatological and meteorological conditions during the 2011 summer and August, and also some selected days for the great forest fires occurred in August and September in Turkey, we used the NCEP Reanalysis Derived data, which was provided by the NOAA/OAR/ESRL PSD, Boulder, Colorado, USA, from their Web site at http://www.esrl.noaa.gov/psd/.

\section{Results of the Analysis and Conclusions}

(1) In the year 2011, 3612 ha forest area was burned and harmed with 1954 forest fires in Turkey, according to the forest fire data derived from the official information supported by the Turkish Ministry of Forestry and Water Affairs. The greatest number of forest fire events occurred in the forest province of the Muğla Regional Forest Service (RFS) with a figure of 267, while the larger burned forest area with a 733 ha was recorded in the forest province of the İzmir RFS. In 2011, almost half of the number of forest fire events and 61 per cent of the burned area occurred in summer season; whereas the greatest number of forest fire events and the largest burned forest area occurred in September with a figure of 518ha and in August with an area of 1764 ha, respectively.

(2) Keetch-Byram Drought Index (KBDI) was below the index value of 100 during the first 5 months of the year 2011, and thus the probability of fire risk was also at zero level. During these 5 months, about 100 ha forest area was lost due to the events of 124 forest fires in Turkey. 
Türkeş, M., \& Altan, G. (2014). Türkiye'de 2011'de oluşan orman yangınlarının klimatolojik çözümlemesi ve hidroklimatik, yüzey hava ve yüksek atmosfer koşulları ile bağlantiları. International Journal of Human Sciences, 11(1), 145-176.

As of the June 2011, the KBDI tended to increase and led fire probability to increase from no fire risk to the low level of fire risk. In this month, probability of fire risk climbed up the moderate risk level in the Şanlı Urfa forest province of the continental South-eastern Anatolia region, which was already most dry and warm compared with other RFS provinces. The month of June 2011 was characterised with 120 forest fire events and 70 ha burned forest area, which was equal to total number of forest fires and less than magnitude of the burned areas occurred in the first month of the year.

(3) In the month of July, the KBDI further increased and caused to grow the probability of fire risk to the high level, mainly because of decreased or being zero precipitation and continuing increase in daily mean and maximum air temperatures, and associated significant decreasing in relative humidity and drying in soil moisture, etc. In this month, the KBDI reached a high level of fire risk probability with the indices varying from 400 at the north and 600 at the south of the country. A number of 332 forest fires and a burned area of 385 ha have proved us the degree of increased fire risk.

(4) In August 2011, the KBDI reached the highest levels of forest fire risk, leading occurrence of the higher number of fire events and larger burned areas in comparison with rest of the year. In this month, Kahraman Maraş, Elazı̆̆ Antalya, Muğla and Konya RFS provinces were characterised with the level of definite fire risk probability, while rest of Turkey other than these provinces had the level of very high fire risk, and a total forest area of 1764 ha was burned and destroyed by a total number of 482 forest fires.

(5) All the climatological and meteorological explanations and comparisons performed in this paper, which are mainly based on our detailed analysis to determine the spatial and temporal variations of the KBDI, and the relationship between hydro-climatic, synoptic-scale surface weather and upper atmosphere conditions, and occurrence time and magnitude of the 2011 forest fires in Turkey, depicted that both the probability of fire risk and probable forest fires that may transform to greater forest fires would be considerable high in summer season (Figure 10 and 11) and particularly in August (Figure 12 and 13). In this point, it should also be stressed that the prevalent surface soil, surface weather and upper atmosphere conditions, which were characterised with the features of much warmer and drier, more stable, lower humidity and higher dew deficient, respectively, in dry and warm summer of 2011 transferred to the following month of September, and thus the September started with this fire-prone weather conditions (Figure 14 and 15). It is not surprising result that most of the great forest fires in 2011 occurred in August in terms of the magnitude of forest fire number and burned area, except that on the day of 2 September, 2011, day of which had the greatest number of the forest fire occurred only in one day.

(6) As we already discussed in the paper in detail, it is suggested here that the great Bayramiç (a town of Çanakkale near by the Mount Ida) forest fire occurred on the day of 18 August, 2011 must be associated very likely with hydro-climatic and atmospheric conditions such as dominant strong and persistent northerly winds (particularly Etesian or summer north-easterly or yaz Poyrazı in Turkish), very low or near zero air and soil moisture and low precipitable water amount affected both in generally 2011 summer and August and on the days of 17-18 August, in addition to probable local fire management mistakes and insufficient mitigation facilities and/or action plans, etc. KBDI and other drought indices also supported to this synthesis or hypothesis mainly based on the hydro-climatic and synoptic-scale weather type analysis performed not only Turkey and its surrounding regions but also the larger Mediterranean Basin seen in the figures between Figure 10 to Figure 15. For the case of 18 August Bayramiç forest fire, index values of the KBDI calculated using the data recorded at the nearby meteorological stations of Çanakkale (at north) and Balıkesir (at south) were at the levels of very high fire probability with the indices of 463 and 539, respectively. 
Türkeş, M., \& Altan, G. (2014). Türkiye'de 2011'de oluşan orman yangınlarının klimatolojik çözümlemesi ve hidroklimatik, yüzey hava ve yüksek atmosfer koşulları ile bağlantilar1. International Journal of Human Sciences, 11(1), 145-176.

(7) In the other great summer forest fires of 2011, for instance those occurred on the days of 23 and 24 August, 352 ha and 137 ha forest areas belong to Seferihisar and Bergama forest management administrations of İzmir RFS (Figure 4a), respectively, were burned and harmed under the similar hydroclimatic and synoptic-scale surface weather and upper atmospheric condition that occurred on 18 August, 2011, such as dominant strong and persistent northerly and north-easterly winds, very low or near zero air and soil moisture and low precipitable water amount. During these two days of 23 and 24 August, the KBDI values of Izmir meteorological station climbed up 618 and 623, respectively, with the level of definite fire probability.

(8) In addition to the forest fire-prone summer warmth and dryness, drought events and conditions dominated in September as a continuation of the August, while in the month of October, level of fire risk probability tended to decrease due to beginning of the autumn precipitation. In September, probability level of the fire risk was at the very likely high level and definite fire occurrence level over eastern, southern, mid-western regions and surroundings of the Sea of Marmara of Turkey, whereas lower fire risk probability levels appeared at the north on the coastal belt of the Black Sea region of the country. In September, 635 ha forest area was burned and destroyed because of a total 518 forest fires, while 305 ha forest area was burned and destroyed with a total 188 forest fires in October.

(9) The sufficient qualitative and quantitative scientific studies that analysed and explained the relationships between the forest fires and climatological and meteorological (surface weather and upper atmospheric, climatic, climate change and variability) conditions and factors in Turkey by using examples from various forest, biogeographical or ecological regions have started recently, even though these attempts and studies were realised very lately. Thus, these kinds of analytical spatial and temporal studies and statistical comparisons, which should also take into consideration of the observed (present) and projected (future) climate changes and variability, and changes in extreme weather and climate events and disasters, and their very likely results and impacts, should be performed systematically in Turkey (e.g. Altan et al., 2011; Tatlı and Türkeş, 2013; Türkeş and Altan, 2012abc; 2013ab; Türkeş et al., 2011b, 2012, vb.).

(10) In Turkey, only some limited areas of forest ecosystems have been protected with various forest management and conservation areas and structures with different statutes, in terms of the contemporary concepts dealing with the forest fire mitigation, forest fire risk management and ecosystem approach. Consequently, we would also suggest here that the levels of exposure and vulnerability of the Turkish Mediterranean forest ecosystems to the present and future forest fires should be lowered based on the scientific results, findings and recommendation including those given in this paper and some other studies. 